\section{SM Journal of Biometrics \& Biostatistics}

Article Information

Received date: Nov 01, 2017

Accepted date: Nov 21, 2017

Published date: Nov 27, 2017

\section{*Corresponding author}

SA Kalogirou, Department of Mechanical Engineering and Materials Science and Engineering, Cyprus University of Technology, Limassol, Cyprus, Tel: +357-2500-2621; Fax: +357-25002637; Email: soteris.kalogirou@cut.ac.cy

Distributed under Creative Commons CC-BY 4.0

Keywords Broadband UVA irradiance Statistical analysis; Clearness index; Frequency distribution; Transparency; Statistical relationships; Cyprus

\section{Statistical Analysis and Inter- Comparison of Solar UVA and Global Radiation for Athalassa and Larnaca, Cyprus}

\author{
Pashiardis $\mathrm{S}^{1}$, Kalogirou $\mathrm{SA}^{1 \star}$ and Pelengaris $\mathrm{A}^{2}$ \\ ${ }^{1}$ Department of Mechanical Engineering and Materials Science and Engineering, Cyprus University of \\ Technology, Cyprus \\ ${ }^{2}$ Department of Cyprus Public Works, Ministry of Transport Communications and Works, Cyprus
}

Abstract

A statistical analysis and inter-comparison of the broadband ultraviolet-A (UVA) radiation at two sites in Cyprus representing two different climate regimes of the island (Athalassa-inland plain vs Larnaca-coastal location) covering the period January 2013-December 2015 is presented. Mean annual and mean monthly daily totals of the UVA irradiation and their frequency distribution at both sites are computed and discussed. Daily maximum of hourly average irradiance values occur in July, $58 \mathrm{~W} \mathrm{~m}^{-2}$ and minimum, $22 \mathrm{~W} \mathrm{~m}^{-2}$, in December at solar noon at Athalassa. The respective values at Larnaca are slightly higher $\left(68 \mathrm{~W} \mathrm{~m}^{-2}\right.$ and $28 \mathrm{~W} \mathrm{~m}^{-2}$, respectively). UVA daily values follow the pattern of the solar altitude angle; the total accumulated UVA irradiation along a mean year reaches $385.8 \mathrm{MJ} \mathrm{m}^{-2}$ at Athalassa and $476.5 \mathrm{MJ} \mathrm{m}^{-2}$; maximum stability of UVA takes place at midday hours and during the summer. Large fluctuations of the daily UVA irradiation are observed in the winter and spring months, which are mainly due to unstable meteorological conditions during the transition from cold to warm weather and vice versa. During summer the daily UVA radiation exceeds the value of $1700 \mathrm{~kJ} \mathrm{~m}^{-2}$ at Athalassa and $2100 \mathrm{~kJ} \mathrm{~m}^{-2}$ at Larnaca, while during the winter season the lowest is about $250 \mathrm{~kJ} \mathrm{~m}^{-2}$ at both stations. The UVA potential and extraterrestrial irradiation have also been calculated in order to estimate the attenuation of UVA radiation through the atmosphere. The UVA transmittance, $k_{\text {uYA }}$, is approximately 6 to $7 \%$ of the hemispherical transmittance for the whole spectrum $\left(k_{1}\right)$. Statistical relationships between UVA and other radiation components were established using linear or power relationships.

\section{Introduction}

UV radiation on the Earth's surface varies widely and depends mainly on latitude, solar elevation, ozone column and local atmospheric conditions. The emission of certain gases due to human activity is known to alter the composition of the atmosphere. Some of the most serious damage caused is the reduction of the ozone layer in the stratosphere, causing a corresponding increase in ultraviolet radiation [1]. Measurements in Italy and England indicate that UV incidence increased with decreasing ozone amount at fixed solar zenith angles [2-3]. Ultraviolet (UV) radiation covers wavelengths of the electromagnetic spectrum between 100 and $400 \mathrm{~nm}$ and it constitutes $8.73 \%$ of the total extraterrestrial solar spectrum irradiance. Within the UV radiation spectrum three zones are distinguished in relation to the effects that the radiation produces on living organisms: UVC (100-280 nm), UVB (280-315 nm) and UVA (315-400 nm) [4].

UVC does not reach the earth surface since it is absorbed completely by the ozone layer in the stratosphere. In the upper atmosphere, UVB irradiance amounts to $1.3 \%$ of the solar constant [5]. This component disrupts proteins (DNA), causes skin sunburn, skin cancer and eye cataracts in humans, losses of productivity and other destructive effects in plants [6-9]. Skin overexposure produces severe sunburn that causes heat, erythema and other symptoms approximately 16 hours after exposure to natural sunlight [10]. On the other hand, the primary benefit of human exposure to UVB radiation is the need for UVB for synthesis of vitamin D in the skin. This synthesis is achieved with very low doses of UVB radiation, such that a daily exposure of 10-15 min of the face, arms and hands at the intensity of the radiation received in Northern Europe is sufficient [11]. The ultraviolet A (UVA) irradiance represents around $90-95 \%$ of the UV solar irradiance that reaches the Earth surface and is the less energetic portion of the UV spectrum; it is only slightly absorbed by ozone layer. The health-associated effects of UVA exposure include photo-aging of the skin, immunosuppression of the skin immune system and potential enhancement of the negative effects of UVB exposure [12-13].

The enhanced UV irradiance due to global depletion of stratospheric ozone and the increased cumulative sun exposure of the public are of major concern due to deleterious health-associated effects of increased exposure to UV irradiance. Consequently, there is now added impetus to study 
the temporal and spatial variability of both UVB and UVA irradiance. In spite of the important role of $U V$, few radiometric stations measure systematically the UV solar irradiance in the Mediterranean region. A network of UV stations was established in Greece [14], Spain [1516], Israel [17] and Egypt [18]. In Cyprus, UV radiation is measured currently at two locations: Athalassa (inland) and Larnaca (coastal place) [19-20].

Various authors have analyzed the relation between solar UV and global radiation. Martinez-Lozano et al. [21] studied UV $(A+B)$ irradiance values in Valencia in the period 1991-1994. Foyo-Moreno et al. [22] analyzed UV and global irradiance in Granada. Canada et al. [23] studied UV irradiance in Valencia and Córdoba in relation to the clearness index, the relative optical air mass, the time of year and the total irradiance on a horizontal surface. Mantis et al. [24], Koronakis et al. [25], Kudish and Evseev [26-27], Jacovides et al. [19-20,28] performed statistical analysis of various components of UV radiation and global irradiances in Athens (Greece), Beer Sheva (Israel) and Athalassa (Cyprus), respectively, Recently, Kalogirou et al. [29] and Pashiardis et al. [30] performed statistical analysis on temporal and spatial variability of erythemal and UVB solar radiation components, respectively and compared two sites in Cyprus with different climate regimes.

An assessment of the solar radiation climate of the Cyprus environment was presented by Jacovides et al. in 1993 [31]. Kambezides [32] presented the 'Typical Meteorological Year' for Nicosia. More recently, Kalogirou et al. [33] presented a statistical analysis and inter-comparison of the solar global radiation at the above two sites in Cyprus using measurements of 21 months at both sites. The common feature of all the above studies is that they rely mostly on measurements of solar radiation carried out in the actinometric stations of Athalassa and Larnaca.

The present study is based upon broadband measurements of UVA irradiance. The aim of the study is the statistical analysis of the temporal and spatial variability of UVA irradiance at two sites in Cyprus (inland and coastal). This is essential because of the fact that the atmospheric conditions in the area favour dry summers and cold winters, high air temperatures and low vapour pressure values at midday in summer time which affect the transition of UVA through the atmosphere. In this work we analyze hourly UVA and global irradiance data on a horizontal plane and perform an inter-

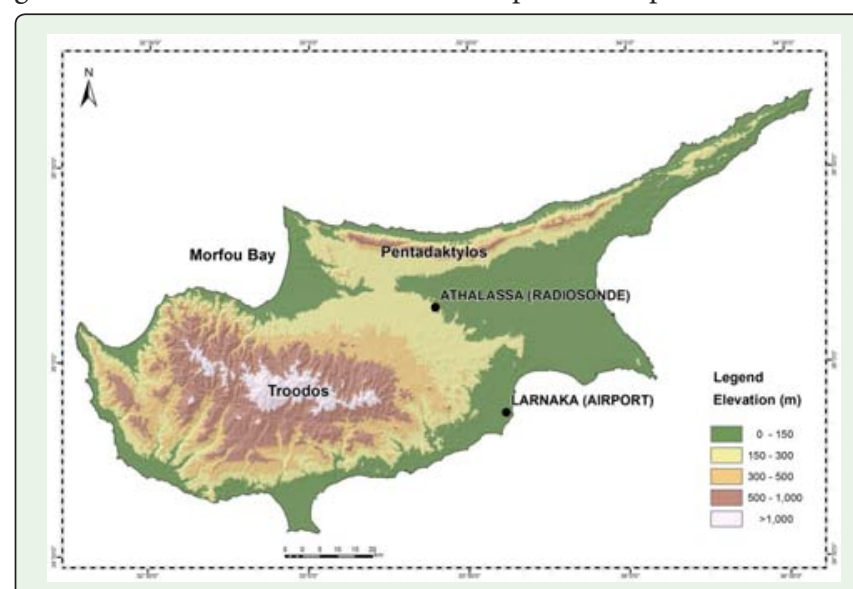

Figure 1: Map of Cyprus showing the location of the two radiometric stations. comparison study between the two locations in Cyprus as well as between other sites in the Mediterranean region.

Topography, Climatology, Measurements and Quality Control

\section{Topography and climate characteristics of the two sites}

The radiation data on which this study is based are being monitored at two meteorological stations: one located at Athalassa, an inland plain location and the other one at Larnaca Airport which is near the coast (Figure 1). The site parameters of the two stations are listed in table1.

The climate of both stations is typical Mediterranean with mild winters (mean seasonal air temperature of about $12{ }^{\circ} \mathrm{C}$ at Larnaca and $10.5{ }^{\circ} \mathrm{C}$ at Athalassa) and warm summers (mean seasonal air temperature of $27.5^{\circ} \mathrm{C}$ at Larnaca and $29.5^{\circ} \mathrm{C}$ at Athalassa). At Larnaca Airport sea-breeze cells develop in late spring and summer. Although Athalassa is an inland location, a westerly sea-breeze is mainly noticeable during the summer time blowing from the Morphou bay between the mountainous ranges of Pentadactylos and Troodos (Figure 1). The annual rainfall is about $320 \mathrm{~mm}$ at Athalassa and about $340 \mathrm{~mm}$ at Larnaca. Most of the rainfall occurs between October and March; summer months are mostly dry. The two sites are characterised by relatively high global and horizontal beam radiation intensities. The average annual sunshine duration is 3332 hours for Athalassa and slightly higher at Larnaca (3368 h). All the above climatic averages refer to the 1981-2010 period.

The annual average daily global radiations exceed $18.5 \mathrm{MJ} \mathrm{m}^{-2}$ at the two sites, whereas the horizontal beam radiation is $13.1 \mathrm{MJ} \mathrm{m}^{-2}$ for Athalassa and 14.2 $\mathrm{MJ} \mathrm{m}^{-2}$ for Larnaca, respectively. Consequently, the fraction of the beam component of the global radiation is relatively high at both sites, viz., the annual average daily fraction is $>0.600$ at the two sites. Comparing the two sites it seems that Larnaca has slightly higher rates of global radiation than Athalassa, since the average yearly cumulative global irradiation is $6835 \mathrm{MJ} \mathrm{m}^{-2}$ for Athalassa and $7183 \mathrm{MJ} \mathrm{m}^{-2}$ for Larnaca. The monthly average frequency of days according to the classification of the magnitude of the daily clearness index $K_{T}$ (daily global to daily extraterrestrial radiation), showed that both clear and partially cloudy days exceed $90 \%$ annually $\left(K_{T}>0.35\right)$ [33].

\section{Measurements and quality control processes}

The period for presenting the data in both stations is January 2013 until December 2015 (3years), when both stations operated simultaneously, so as to allow for comparison of the different variables of solar and terrestrial radiation. Measurements of total solar irradiance on a horizontal surface were taken with Kipp\&Zonen CM11 pyranometers whose spectral range is from 285 to $2800 \mathrm{~nm}$. Both stations are equipped with Kipp\&Zonen UVS-AB-T broadband radiometers with spectral range 280 to $315 \mathrm{~nm}$ (UVB) and 315 to 400 $\mathrm{nm}$ (UVA). The radiometers have directional response up to $70^{\circ}$ solar zenith angle $\left(\theta_{z}\right)$ less than $2.5 \%$. All the sensors are factory calibrated, Table 1: Site parameters for the two meteorological stations.

\begin{tabular}{|c|c|c|c|c|}
\hline Site & Location & Latitude & Longitude & Altitude (m,m.s.l) \\
\hline Athalassa & inland & $35.141^{\circ} \mathrm{N}$ & $33.396^{\circ} \mathrm{E}$ & 165 \\
\hline Larnaca & coastal & $34.873^{\circ} \mathrm{N}$ & $33.631^{\circ} \mathrm{E}$ & 1 \\
\hline
\end{tabular}


in accordance with the World Radiometric Reference (WRR). Global radiation instruments are calibrated outdoor against standard references at irregular time intervals during the study period. The errors involved in the radiation measurements are found to be no less than $\pm 2 \%$ for the normal incidence beam irradiance and $\pm 3 \%$ for the global irradiance.

A Campbell Scientific Instruments data-logger, located at each site (Model CR10), monitors and stores the data at 10-min intervals (the meters are scanned every 10-seconds and average, maximum, minimum and instantaneous values at 10-min intervals are calculated and stored). The stored data are downloaded to a desktop computer periodically. The data refer to the Local standard Time (LST=GMT+2). About $5 \%$ of the data values are missing because of some problems with the instruments and some defects and maintenance in the data acquisition systems. The validity of the individual measurements was checked in accordance with WMO recommendations [34] and other tests proposed by various authors [35-37]. Details about the quality control procedures used in this study are given by Pashiardis and Kalogirou [38]. All data that do not meet the conditions specified by the suggested tests are not used in the study.

Regarding the UVA irradiance the following upper limit was applied as suggested by Miguel et al. [39]:

$$
U V A \leq 1.2 * U V A_{0}
$$

Where, UVA is the measured value and $U V A_{0}$ is the horizontal extraterrestrial solar UVA irradiance. The measurements of both stations were less than the horizontal extraterrestrial solar UVA irradiance during the whole period of measurements (Figure 2). The values of UVA irradiance during the night were close to zero. No other errors were detected. Long missing data were detected during the measurement period (2013-2015) at Larnaca due to instability of the system.

Regarding the quality control of the daily UVA radiation data, daily values were rejected in case of incomplete data during the day. The time series plots of the daily values of UVA irradiation for both stations are shown in figure 3. The figure indicates that the ascent during the first months of each year is very irregular with fluctuations, while the descent is smoother. During summer the daily UVA radiation exceeds the value of $2000 \mathrm{~kJ} \mathrm{~m}^{-2}$ at Larnaca and $1800 \mathrm{~kJ} \mathrm{~m}^{-2}$ at Athalassa, while during the winter season the lowest daily value is

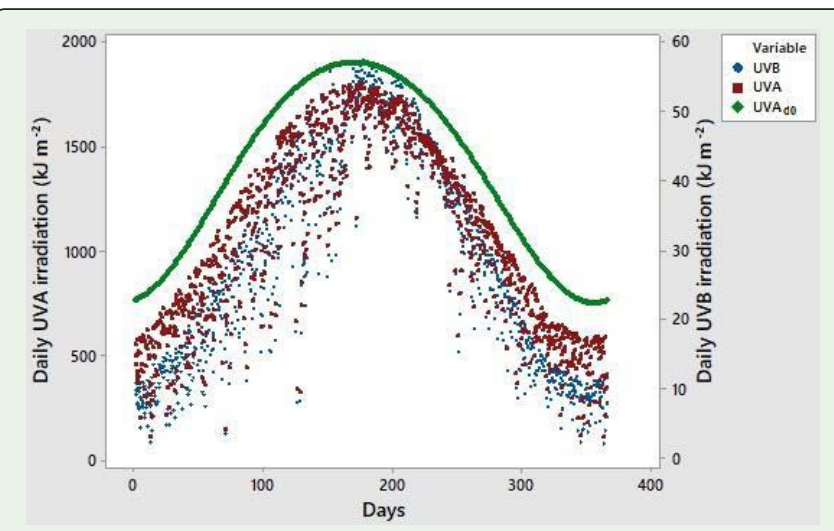

Figure 2: Daily values of UVA and UVB irradiation $\left(\mathrm{kJ} \mathrm{m}^{-2}\right)$ at Athalassa and daily extraterrestrial UVA (UVA $\left.A_{d 0}\right)$ irradiation $\left(\mathrm{kJ} \mathrm{m}^{-2}\right)$. about $110 \mathrm{~kJ} \mathrm{~m}^{-2}$ at both stations. Comparing daily UVA and UVB radiation it seems that UVA is about 50 times more than UVB in mid-winter and about 30 times more in mid-summer at both stations.

\section{Results and Discussion}

\section{Data variation}

Global solar radiation and total UVA radiation have been analysed and compared in this study. Figure 4a shows temporal evolution of UVA and global solar radiation at Athalassa. A similar graph with slightly higher values was obtained at Larnaca (Figure 4b). Data reveal a common evolution shape with maxima in summer and minima in winter, mainly due to the daily minimum solar zenith angle and day-length (astronomical factors) variation during the year. Large fluctuations in the spring months and November are mainly due to unstable meteorological conditions during the transition from cold to warm weather and vice versa. The maximum of daily global solar horizontal irradiation is reached in June or July and is around $31 \mathrm{MJ}$ $\mathrm{m}^{-2}$ at Athalassa and around $32 \mathrm{MJ} \mathrm{m}^{-2}$ at Larnaca.

\section{Statistical analysis of hourly UVA irradiance}

A statistical study of the most representative UVA indices for each month of the year has been carried out and the UVA accumulated values have been evaluated because they are very useful in the studies of effects on human beings.

Table 2 shows the hourly statistical estimators for July for both stations. The statistical parameters presented in the Table are: Number of Data $(N)$, Arithmetic Mean (Mean), Standard Deviation (StDev), Coefficient of Variation ( $\mathrm{CV}$ in \%), Minimum (Min), First Quartile (Q1), median, third quartile (Q3), Maximum (Max), Interquartile Range $(I Q R)$, percentile $5\left(P_{5}\right)$ and percentile $95\left(P_{95}\right)$ [20]. It can be observed that the median values are slightly higher than the average ones at least during the middle hours of the day.

The difference between the Q3 quartiles and the maximum values are low, with the highest ones not exceeding $2.20 \mathrm{~W} \mathrm{~m}^{-2}$ for Athalassa and $3.86 \mathrm{~W} \mathrm{~m}^{-2}$ for Larnaca; this result shows that the maximum values are representative of the UVA irradiance. On the other hand the differences between Q1 quartiles and minimum values are relatively high $\left(>5 \mathrm{~W} \mathrm{~m}^{-2}\right)$ in most cases. Similarly, the difference between the minimum values $(\mathrm{Min})$ and the percentile, $P_{5}$, is very high $\left(>4 \mathrm{~W} \mathrm{~m}^{-2}\right)$ at both stations, which suggests that the minimum

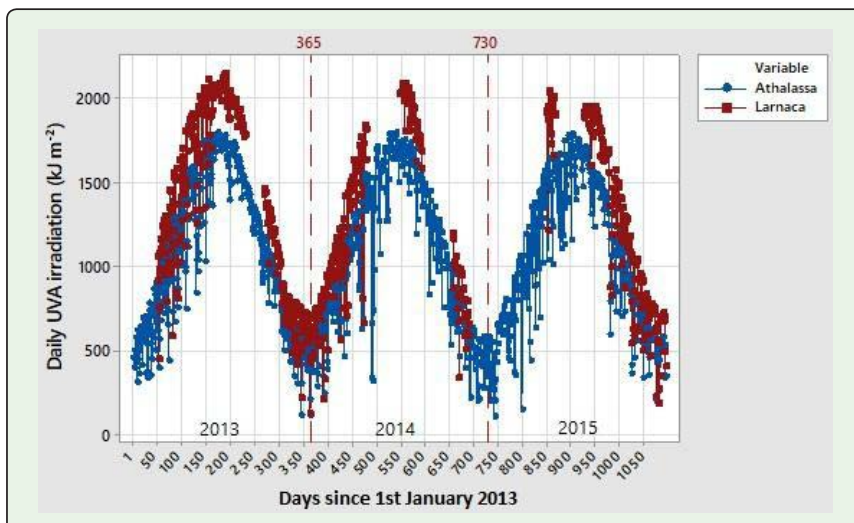

Figure 3: Time series plot of daily UVA solar irradiation during the period 2013-2015 at Athalassa and Larnaca. 
Table 2: Statistical estimators of the mean hourly UVA irradiance $\left(\mathrm{W} \mathrm{m}^{-2}\right)$ in July, under all sky conditions, for the period 2013-2015, for a) Athalassa and b) Larnaca. a) Athalassa

\begin{tabular}{|c|c|c|c|c|c|c|c|c|c|c|c|c|}
\hline Hour & $\mathbf{N}$ & Mean & StDev & CV (\%) & Min & Q1 & Median & Q3 & Max & IQR & $P_{5}$ & $P_{95}$ \\
\hline 6 & 93 & 5.06 & 0.75 & 14.92 & 2.32 & 4.61 & 5.13 & 5.55 & 6.56 & 0.94 & 3.60 & 6.26 \\
\hline 7 & 93 & 12.22 & 1.54 & 12.60 & 6.59 & 11.37 & 12.47 & 13.20 & 15.04 & 1.84 & 9.17 & 14.54 \\
\hline 8 & 92 & 23.89 & 1.91 & 8.01 & 18.13 & 23.01 & 24.26 & 25.07 & 27.24 & 2.06 & 20.19 & 26.74 \\
\hline 9 & 92 & 36.01 & 1.81 & 5.01 & 30.10 & 34.89 & 36.23 & 37.24 & 39.44 & 2.35 & 32.85 & 38.76 \\
\hline 10 & 92 & 46.49 & 1.98 & 4.25 & 37.07 & 45.51 & 46.70 & 47.69 & 49.72 & 2.18 & 43.48 & 49.19 \\
\hline 11 & 92 & 54.03 & 1.82 & 3.36 & 47.29 & 53.13 & 54.16 & 55.41 & 57.06 & 2.27 & 50.87 & 56.53 \\
\hline 12 & 92 & 57.53 & 1.89 & 3.29 & 51.62 & 56.64 & 57.75 & 58.83 & 61.03 & 2.19 & 53.40 & 60.21 \\
\hline 13 & 92 & 56.68 & 3.30 & 5.83 & 38.67 & 56.10 & 57.50 & 58.56 & 60.24 & 2.46 & 48.51 & 59.56 \\
\hline 14 & 92 & 51.30 & 4.90 & 9.55 & 29.86 & 51.02 & 53.05 & 53.99 & 55.45 & 2.97 & 39.47 & 55.14 \\
\hline 15 & 92 & 42.51 & 6.86 & 16.14 & 16.69 & 43.03 & 45.23 & 46.03 & 47.75 & 3.01 & 23.26 & 47.06 \\
\hline 16 & 92 & 33.44 & 4.26 & 12.74 & 6.82 & 33.28 & 34.67 & 35.57 & 37.22 & 2.29 & 23.84 & 36.38 \\
\hline 17 & 92 & 22.52 & 2.03 & 9.02 & 11.11 & 22.11 & 22.97 & 23.63 & 25.24 & 1.52 & 18.78 & 24.49 \\
\hline 18 & 92 & 11.41 & 0.98 & 8.63 & 7.06 & 10.88 & 11.52 & 12.08 & 13.17 & 1.20 & 9.78 & 12.96 \\
\hline 19 & 92 & 5.48 & 0.57 & 10.37 & 2.92 & 5.15 & 5.48 & 5.82 & 6.63 & 0.67 & 4.67 & 6.36 \\
\hline
\end{tabular}

b) Larnaca

\begin{tabular}{|c|c|c|c|c|c|c|c|c|c|c|c|c|}
\hline Hour & $\mathbf{N}$ & Mean & StDev & CV (\%) & Min & Q1 & Median & Q3 & Max & IQR & $P_{5}$ & $\mathbf{P}_{95}$ \\
\hline 6 & 77 & 5.10 & 1.12 & 21.97 & 2.07 & 4.38 & 4.99 & 5.97 & 7.45 & 1.60 & 3.57 & 7.04 \\
\hline 7 & 77 & 13.15 & 2.72 & 20.65 & 9.26 & 10.93 & 12.17 & 15.72 & 19.00 & 4.79 & 9.73 & 17.91 \\
\hline 8 & 77 & 26.71 & 3.73 & 13.96 & 19.32 & 23.91 & 25.71 & 30.16 & 34.02 & 6.25 & 20.40 & 32.71 \\
\hline 9 & 77 & 40.83 & 3.96 & 9.70 & 29.57 & 37.98 & 41.01 & 44.29 & 47.93 & 6.31 & 34.12 & 46.97 \\
\hline 10 & 77 & 53.43 & 3.62 & 6.77 & 41.50 & 50.76 & 53.84 & 56.23 & 59.78 & 5.47 & 47.99 & 58.98 \\
\hline 11 & 77 & 62.77 & 3.09 & 4.92 & 52.36 & 60.51 & 63.14 & 64.76 & 68.21 & 4.25 & 57.95 & 67.48 \\
\hline 12 & 77 & 68.13 & 2.66 & 3.90 & 61.45 & 66.27 & 68.77 & 69.87 & 72.78 & 3.60 & 63.24 & 72.19 \\
\hline 13 & 77 & 68.56 & 2.27 & 3.32 & 63.38 & 67.14 & 68.72 & 70.19 & 72.59 & 3.06 & 63.77 & 71.71 \\
\hline 14 & 77 & 63.78 & 2.36 & 3.70 & 59.38 & 61.78 & 63.72 & 65.84 & 68.00 & 4.06 & 59.62 & 67.40 \\
\hline 15 & 77 & 54.35 & 4.05 & 7.46 & 25.56 & 52.97 & 54.21 & 56.65 & 59.82 & 3.68 & 51.33 & 58.51 \\
\hline 16 & 77 & 41.50 & 3.83 & 9.23 & 24.05 & 40.01 & 41.85 & 43.61 & 47.73 & 3.60 & 31.63 & 40.10 \\
\hline 17 & 77 & 27.42 & 2.89 & 10.54 & 16.38 & 24.80 & 27.34 & 29.72 & 32.60 & 4.92 & 23.64 & 31.77 \\
\hline 18 & 77 & 13.35 & 1.98 & 14.79 & 5.08 & 11.63 & 13.47 & 14.77 & 16.76 & 3.14 & 10.98 & 16.33 \\
\hline 19 & 68 & 6.95 & 0.87 & 12.47 & 4.53 & 6.39 & 7.01 & 7.71 & 8.38 & 1.33 & 5.63 & 8.15 \\
\hline
\end{tabular}

values are not representative of the UVA irradiance at the station level and correspond to unusual extreme values, particularly in summer. Similar results have been obtained by Martinez-Lozano et al. [21] Foyo-Moreno et al. [22] and Bilbao et al. [15] for a number of stations in Spain. On the other hand the difference between the maximum, Max and the percentile, $P_{95}$, is quite small. In July the differences are lower than $<1 \mathrm{~W} \mathrm{~m}^{-2}$ at both stations. The absolute maximum values of the two stations were $61.03 \mathrm{~W} \mathrm{~m}^{-2}$ for Athalassa and $72.78 \mathrm{~W} \mathrm{~m}^{-2}$ for Larnaca.

The UVA variability has been studied by means of the Coefficient of Variation $(C V)$. As it can be seen in table 2, the $C V$ s in July are low during the midday (3-9\%) at both stations, indicating a high stability along these hours in summer. Furthermore, $C V s$ fluctuate between 3 and $15 \%$ at Athalassa, while at Larnaca is slightly higher (3-22\%). The standard deviation is lower along midday hours and symmetrically distributed around solar noon during the summer months. This could be explained by a minor presence of clouds in the summer months that lead to a high stability.

\section{Analysis of monthly average hourly UVA irradiance}

The daily variation of the average hourly UVA irradiance is shown in figure 5 . The figure shows that UVA irradiance fluctuates between $22.28 \mathrm{~W} \mathrm{~m}^{-2}$ in December and $52.53 \mathrm{~W} \mathrm{~m}^{-2}$ in July at solar noon at Athalassa. The values at Larnaca are higher than in Athalassa and they fluctuate between $28.51 \mathrm{~W} \mathrm{~m}^{-2}$ in December and $68.56 \mathrm{~W}$ $\mathrm{m}^{-2}$ in June at solar noon. A high symmetry is also observed around the months of June or July when the irradiance reaches its maximum, while it decreases in spring and autumn and reaches its minimum in winter months. The results can be explained by taking into account the symmetry relation between the summer and winter solstices. 


\section{Analysis of accumulated UVA irradiation}

In the studies on the biological effects of UVA irradiation or the availability of solar energy for technological applications, we require the accumulated UVA solar irradiation $\left(\mathrm{kJ} \mathrm{m}^{-2}\right)$ through a period of time. Figure 6 shows the accumulated hourly UVA irradiation values for an average day of each month and the last value is the total daily amount. It can be seen that the highest value for UVA irradiation was produced in July, with a daily average of $1650.8 \mathrm{~kJ} \mathrm{~m}^{-2}$ for Athalassa, while at Larnaca the highest is recorded in June $\left(2000.9 \mathrm{~kJ} \mathrm{~m}^{-2}\right)$. On the other hand, in December the average energy received was a minimal $467.5 \mathrm{~kJ} \mathrm{~m}^{-2}$ at Athalassa and $609.4 \mathrm{~kJ} \mathrm{~m}^{-2}$ at Larnaca. The accumulated irradiation received in an average year is $385.8 \mathrm{MJ} \mathrm{m}^{-2}$ for Athalassa and $476.5 \mathrm{MJ} \mathrm{m}^{-2}$ for Larnaca.

\section{Monthly mean hourly UVA/G ratio}

The increase of $U V A / G$ ratio with the cloud cover is significantly higher for low solar elevation. The monthly mean of the hourly $U V A / G$ ratio is given in table 3 . The monthly mean hourly ratio is almost constant throughout the year at both stations. The annual mean hourly ratio is 0.0587 at Athalassa and slightly higher at Larnaca (0.0667).

\section{Influence of solar elevation on UVA irradiance}

The most important factor which affects the solar radiation is the solar elevation. This variable determines the optical path of solar rays

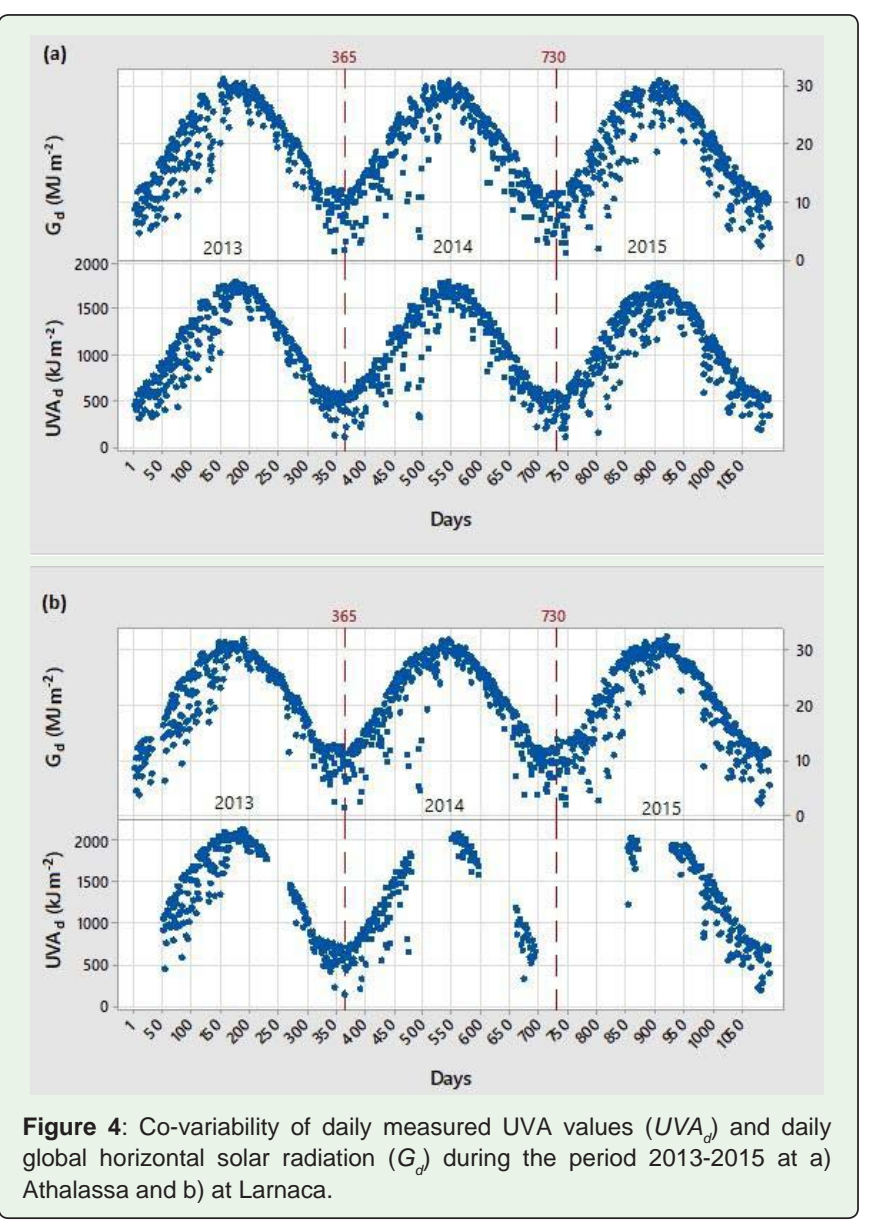

from the top of the atmosphere until they reach the Earth's surface. The solar elevation is related to the optical air mass, that is defined as the ratio between the relative optical air mass in a given direction and the optical mass in a vertical direction and is calculated using the equation suggested by Kasten and Young, [40]:

$$
m=1 /\left(\cos \theta_{z}+0.050572\left(96.07995-\theta_{z}\right)^{-1.6364}\right)
$$

Where $\theta_{z}$ is the zenith angle of the Sun (complementary angle of the solar elevation).

Table 3: Mean monthly of the hourly UVA/G ratio for Athalassa and Larnaca during the period 2013-2015.

\begin{tabular}{|c|c|c|}
\hline Month & Ath & Lca \\
\hline 1 & 0.0579 & 0.0682 \\
\hline 2 & 0.0578 & 0.0649 \\
\hline 3 & 0.0574 & 0.0661 \\
\hline 4 & 0.0574 & 0.0661 \\
\hline 5 & 0.0594 & 0.0672 \\
\hline 6 & 0.0617 & 0.0658 \\
\hline 7 & 0.0585 & 0.0656 \\
\hline 8 & 0.0583 & 0.0655 \\
\hline 10 & 0.0596 & 0.0635 \\
\hline 11 & 0.0613 & 0.0682 \\
\hline 12 & 0.0567 & 0.0672 \\
\hline Year & 0.0574 & 0.0721 \\
\hline
\end{tabular}
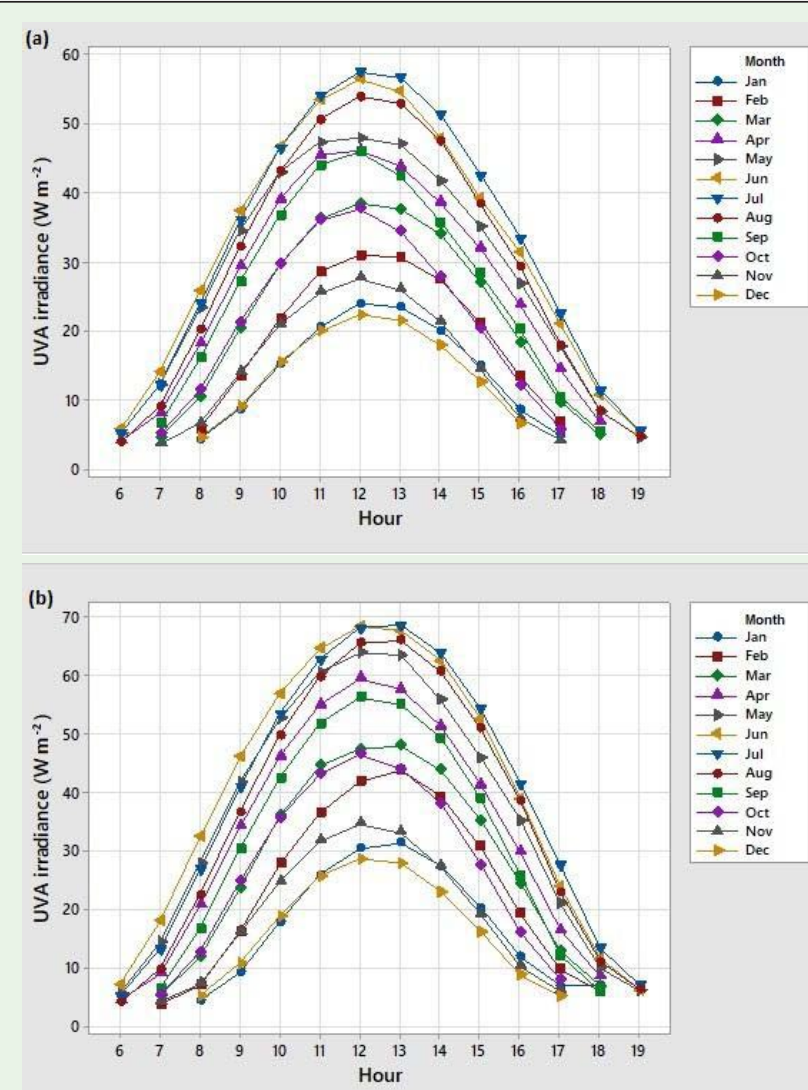

Figure 5: Daily evolution of the monthly mean hourly UVA irradiance $\left(\mathrm{W} \mathrm{m}^{-2}\right)$ for the period 2013-2015 at a) Athalassa and b) Larnaca. 
Table 4: Relationship between UVA irradiance $\left(\mathrm{W} \mathrm{m}^{-2}\right)$ and optical air mass $(\mathrm{m})$ for three different classes of clearness index $\left(k_{t}\right)$ at Athalassa and Larnaca.

\begin{tabular}{|c|c|}
\hline $\begin{array}{c}\text { Hourly } \\
\text { Clearness } \\
\text { Index }\left(\mathrm{k}_{\mathbf{t}}\right)\end{array}$ & \multicolumn{1}{c|}{ Equation } \\
\hline $\mathrm{k}_{\mathrm{t}}>0.65$ & UVA_Ath $=58.144^{*} m^{-1.227}$ \\
\hline $0.35<\mathrm{k}_{\mathrm{t}} \leq 0.65$ & UVA_Ath $=44.075^{*} \mathrm{~m}^{-1.169}$ \\
\hline $\mathrm{k}_{\mathrm{t}}<0.35$ & UVA_Ath $=18.776^{*} m^{-0.853}$ \\
\hline $\mathrm{k}_{\mathrm{t}}>0.65$ & UVA_Lca $=69.534^{*} \mathrm{~m}^{-1.217}$ \\
\hline $0.35<\mathrm{k}_{\mathrm{t}} \leq 0.65$ & UVA_Lca $=50.766 * m^{-1.138}$ \\
\hline $\mathrm{k}_{\mathrm{t}}<0.35$ & UVA_Lca $=24.921 * m^{-0.991}$ \\
\hline
\end{tabular}

To quantify the effect of solar elevation on UVA irradiance, the optical air mass, $\mathrm{m}$, was calculated at the midpoint of each hour. Figure 7 shows the relationship between UVA irradiance and optical air mass for three different classes of hourly clearness index $\left(\mathrm{k}_{\mathrm{t}}\right)$, (the ratio of global irradiance at the Earth surface to the global solar extraterrestrial irradiance both measured on a horizontal surface),i.e., $\left(\mathrm{k}_{\mathrm{t}}\right)>0.65$ (clear hours), $0.35<\mathrm{k}_{\mathrm{t}} \leq 0.65$ (partly cloudy hours) and $\mathrm{k}_{\mathrm{t}}<0.35$ (cloudy hours). It can be seen that, despite the wide dispersion of data, the highest values of UVA irradiance decrease with the optical air mass. Therefore, the solar elevation plays an important role on the levels of UVA irradiance, since it is an important factor in the calculation of the optical air mass (Equation 2). The range of dispersion of the data for the case of clear hours is smaller comparing to the other two
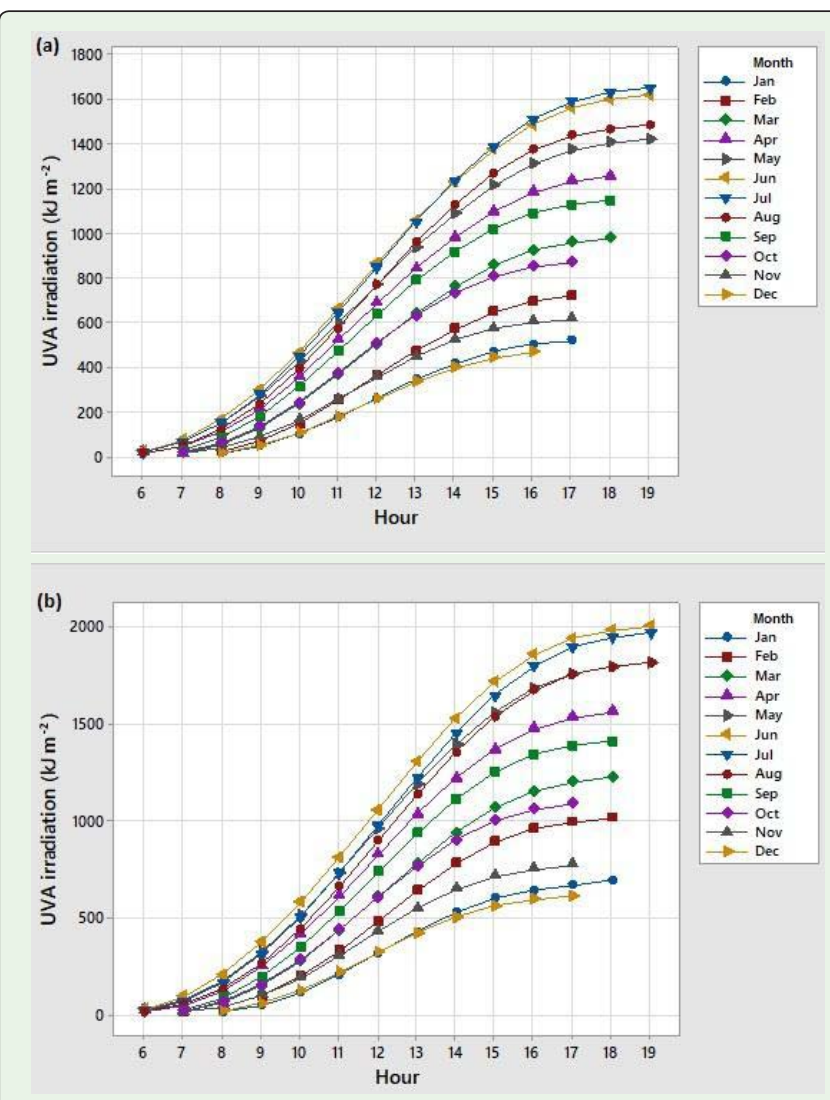

Figure 6: Accumulated hourly UVA values for a mean day of each month (kJ $\mathrm{m}^{-2}$ ), during the period 2013-2015 at a) Athalassa and b) Larnaca. classes. The equations which describe the above relationships for each class of hourly clearness index are presented in table 4 . The equations can be used for the estimation of the hourly UVA irradiance. The relationships have the following form: $\quad U V A=a^{*} m^{b}$

\section{Analysis of UVA daily time series}

Daily and monthly average daily UVA irradiation values have been calculated and figure 8 shows the results for both stations. The daily values present a greater fluctuation in spring season. It can be seen that the variation of the monthly mean values (continuous smooth line) is quite regular, with the maximum values taking place in June and July and the minimum in December. Daily UVA increases in spring to summer shown by the slope which is smaller than the decrease in autumn.

Table 5 shows the statistical characteristics of daily UVA data for all-sky conditions. The median values are mainly higher than the average ones and the maximum of the standard deviation occurs in May; the coefficient of variation shows the lowest values in the summer months, which means that the highest stability is observed in these months. The differences between the minimum, (Min) and the percentile, $P_{5}$ are quite high and therefore, the minimum values correspond to unusual extreme values. On the other hand, the differences between the maximum, (Max) and the percentile $P_{95}$ are small. The observed daily maximum is occurred in June at Athalassa $\left(1797 \mathrm{~kJ} \mathrm{~m}^{-2}\right)$ and in July at Larnaca $\left(2140 \mathrm{~kJ} \mathrm{~m}^{-2}\right)$. The definition of frequency distribution types is a function of the range of kurtosis $(\mathrm{K})$ and skewness values (As) as suggested by Kudish and Evseev [27].

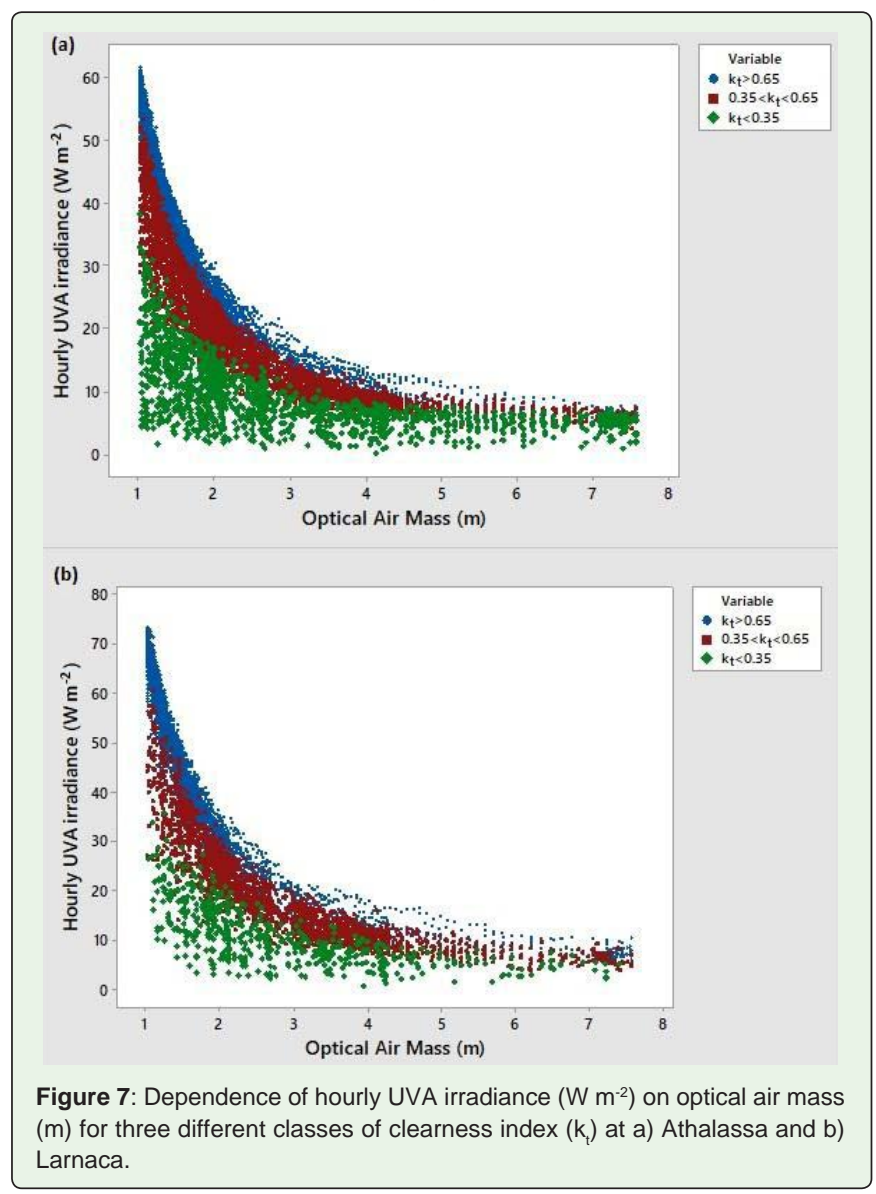


Table 5: Statistical estimators of the daily UVA irradiation values $\left(\mathrm{kJ} \mathrm{m}^{-2}\right)$ at a) Athalassa and b) Larnaca, during the period $2013-2015$.

a) Athalassa

\begin{tabular}{|c|c|c|c|c|c|c|c|c|c|c|c|c|c|c|}
\hline Month & $\mathrm{N}$ & Mean & CV (\%) & Min & Q1 & Median & Q3 & Max & IQR & As & $\mathrm{K}$ & $P_{5}$ & $P_{95}$ & Distr. Type \\
\hline 1 & 93 & 515.4 & 27.22 & 106.5 & 411.6 & 551.0 & 622.5 & 732.1 & 210.9 & -0.72 & -0.18 & 233.5 & 700.5 & IV \\
\hline 2 & 84 & 718.1 & 21.68 & 348.8 & 651.8 & 740.2 & 821.7 & 1020.8 & 169.9 & -0.62 & -0.05 & 390.6 & 945.0 & I \\
\hline 3 & 93 & 973.2 & 23.78 & 146.1 & 856.7 & 994.4 & 1158.3 & 1353.2 & 301.5 & -0.85 & 0.87 & 522.5 & 1282.9 & V \\
\hline 4 & 90 & 1249.7 & 19.60 & 628.5 & 1101.3 & 1300.1 & 1414.7 & 1599.7 & 313.4 & -0.76 & -0.05 & 720.3 & 1568.2 & IV \\
\hline 5 & 90 & 1407.6 & 20.71 & 321.7 & 1262.9 & 1521.2 & 1600.9 & 1742.7 & 338.0 & -1.64 & 3.05 & 793.9 & 1711.7 & V \\
\hline 6 & 89 & 1612.6 & 10.37 & 1125.1 & 1513.6 & 1673.2 & 1745.7 & 1796.8 & 232.1 & -1.13 & 0.45 & 1264.0 & 1785.3 & IV \\
\hline 7 & 92 & 1650.9 & 5.38 & 1306.6 & 1608.1 & 1665.8 & 1711.1 & 1774.4 & 103.0 & -1.35 & 2.23 & 1468.3 & 1756.6 & $\mathrm{~V}$ \\
\hline 8 & 93 & 1467.9 & 6.93 & 1184.8 & 1412.7 & 1479.2 & 1532.5 & 1693.9 & 119.8 & -0.51 & 0.28 & 1249.2 & 1628.5 & IV \\
\hline 9 & 90 & 1140.2 & 14.28 & 590.0 & 1060.8 & 1163.2 & 1262.0 & 1439.6 & 201.3 & -0.90 & 0.84 & 809.9 & 1354.3 & V \\
\hline 10 & 93 & 869.7 & 19.36 & 363.5 & 764.1 & 906.9 & 990.5 & 1137.5 & 226.4 & -0.82 & 0.40 & 536.2 & 1101.6 & IV \\
\hline 11 & 89 & 595.7 & 18.69 & 215.2 & 543.1 & 611.8 & 647.7 & 833.2 & 104.6 & -0.52 & 1.22 & 372.9 & 801.4 & V \\
\hline Year & 1087 & 1056.9 & 42.12 & 106.5 & 638.2 & 1045.2 & 1478.8 & 1796.8 & 840.7 & -0.01 & -1.28 & 396.4 & 1713.8 & VI \\
\hline
\end{tabular}

b) Larnaca

\begin{tabular}{|c|c|c|c|c|c|c|c|c|c|c|c|c|c|c|}
\hline Month & $\mathbf{N}$ & Mean & CV (\%) & Min & Q1 & Median & Q3 & $\operatorname{Max}$ & IQR & As & $\mathbf{K}$ & $\mathbf{P}_{5}$ & $\mathbf{P}_{95}$ & $\begin{array}{l}\text { Distr. } \\
\text { Type }\end{array}$ \\
\hline 1 & 31 & 676.1 & 22.41 & 206.6 & 583.8 & 706.7 & 766.6 & 930.3 & 182.8 & -1.28 & 2.33 & 280.0 & 885.8 & V \\
\hline 2 & 38 & 984.1 & 16.83 & 445.0 & 929.4 & 1011.7 & 1106.4 & 1234.7 & 177.1 & -1.50 & 3.39 & 494.5 & 1218.7 & V \\
\hline 3 & 62 & 1212.5 & 22.64 & 555.3 & 994.0 & 1235.5 & 1454.4 & 1628.0 & 460.4 & -0.45 & -0.60 & 707.6 & 1612.1 & IV \\
\hline 4 & 54 & 1551.0 & 18.74 & 657.1 & 1413.4 & 1628.9 & 1772.4 & 1900.4 & 359.0 & -1.27 & 1.42 & 807.0 & 1884.3 & V \\
\hline 5 & 49 & 1790.9 & 12.23 & 1217.3 & 1664.5 & 1878.8 & 1959.4 & 2057.1 & 294.9 & -1.10 & 0.52 & 1292.2 & 2030.3 & IV \\
\hline 6 & 30 & 1995.8 & 5.86 & 1606.4 & 1991.5 & 2038.5 & 2067.7 & 2108.8 & 76.2 & -2.14 & 4.37 & 1656.8 & 2095.6 & $\mathrm{~V}$ \\
\hline 7 & 77 & 1962.8 & 4.85 & 1593.0 & 1909.2 & 1964.6 & 2024.5 & 2140.2 & 115.3 & -0.74 & 1.78 & 1803.5 & 2103.1 & $\mathrm{~V}$ \\
\hline 8 & 66 & 1798.1 & 5.25 & 1581.7 & 1742.1 & 1810.4 & 1872.0 & 1942.9 & 129.9 & -0.46 & -0.73 & 1626.3 & 1927.5 & IV \\
\hline 9 & 35 & 1400.3 & 14.56 & 824.0 & 1342.0 & 1423.9 & 1501.5 & 1693.7 & 159.5 & -1.15 & 1.82 & 862.6 & 1685.5 & V \\
\hline 10 & 74 & 1082.8 & 17.24 & 540.2 & 982.3 & 1093.4 & 1229.9 & 1372.7 & 247.5 & -0.70 & 0.42 & 714.6 & 1343.1 & IV \\
\hline 11 & 82 & 745.2 & 18.72 & 331.2 & 661.8 & 767.8 & 820.1 & 1036.4 & 158.4 & -0.27 & 0.19 & 485.3 & 974.7 & I \\
\hline 12 & 62 & 592.3 & 26.61 & 124.6 & 511.0 & 650.2 & 712.2 & 769.5 & 201.3 & -1.29 & 1.08 & 213.4 & 754.6 & $\mathrm{~V}$ \\
\hline Year & 660 & 1305.6 & 39.83 & 124.6 & 811.2 & 1292.7 & 1822.6 & 2140.2 & 1011.4 & -0.07 & -1.34 & 543.3 & 2036.3 & VI \\
\hline
\end{tabular}

The most frequent distribution of the monthly daily irradiation at Athalassa is Type IV (almost normal with negative tail) and occurred on 6 occasions. The second frequent type is $\mathrm{V}$ (narrow peak with negative tail) and is recorded in 5 months. February is characterized by Type I normal distribution. At Larnaca, the most frequent distribution of the monthly daily irradiation is Type V (7 months), with the second one of Type IV (4 months). November is characterized by Type I normal distribution. Generally, the distribution types of the daily UVA irradiation for each of the month of the year are similar to those in Israel [27].

Table 6 shows the monthly average daily values of UVA and Global irradiation as well as the daily average ratio UVA/G at both stations. The monthly average ratios are relatively constant throughout the year. The mean annual ratio UVA/G is 0.0570 at Athalassa and 0.0655 at Larnaca. Figure 9 compares the monthly mean daily values of the two stations in Cyprus with two stations in Israel. UVA values at Athalassa are comparable with those in Israel during most of the

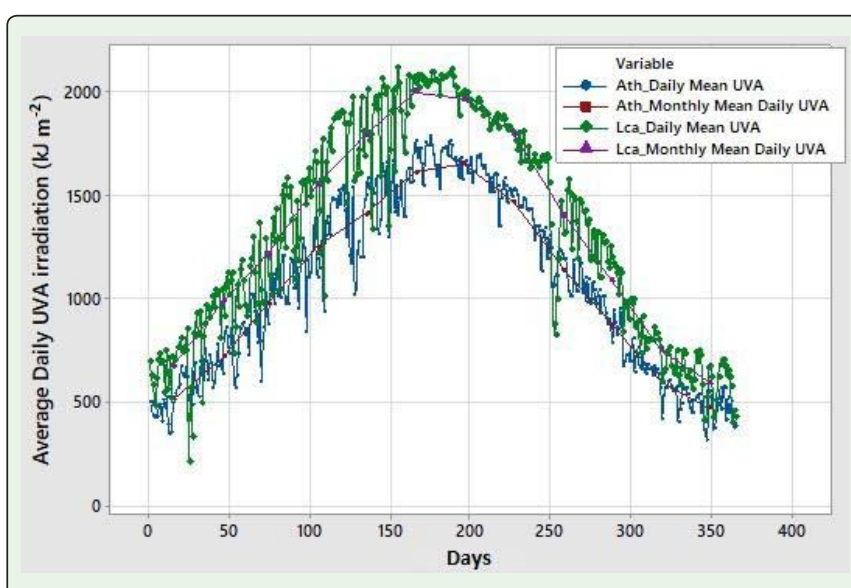

Figure 8: Annual evolution of daily and monthly UVA irradiation values (kJ $\mathrm{m}^{-2}$ ) at Athalassa and Larnaca, during the period 2013-2015. 
Table 6: Average daily UVA and Global irradiation $\left(\mathrm{kJ} \mathrm{m}^{-2}\right)$ and monthly mean ratio UVA/G at Athalassa and Larnaca (2013-2015).

\begin{tabular}{|c|c|c|c|c|c|c|}
\hline & \multicolumn{2}{|c|}{ Daily UVA $\left(\mathbf{k J ~ m}^{-2}\right)$} & \multicolumn{2}{|c|}{ Daily Global (kJ m $\left.\mathbf{~}^{-2}\right)$} & \multicolumn{2}{|c|}{ Daily Ratio (UVA/G) } \\
\hline & Ath & Lca & Ath & Lca & Ath & Lca \\
\hline Month & Mean & Mean & Mean & Mean & Mean & Mean \\
\hline 1 & 515.4 & 676.1 & 9358 & 10012 & 0.0551 & 0.0675 \\
\hline 2 & 718.1 & 984.1 & 13267 & 14345 & 0.0541 & 0.0686 \\
\hline 3 & 973.2 & 1212.5 & 17535 & 18573 & 0.0555 & 0.0653 \\
\hline 4 & 1249.7 & 1551.0 & 22273 & 23921 & 0.0561 & 0.0648 \\
\hline 5 & 1407.6 & 1790.9 & 24053 & 26383 & 0.0585 & 0.0679 \\
\hline 6 & 1612.6 & 1995.8 & 27780 & 29527 & 0.0580 & 0.0676 \\
\hline 7 & 1650.9 & 1962.8 & 27961 & 29261 & 0.0590 & 0.0671 \\
\hline 8 & 1467.9 & 1798.1 & 24913 & 26300 & 0.0589 & 0.0684 \\
\hline 9 & 1140.2 & 1400.3 & 20088 & 21679 & 0.0568 & 0.0646 \\
\hline 10 & 869.7 & 1082.8 & 15511 & 16723 & 0.0561 & 0.0647 \\
\hline 11 & 595.7 & 745.2 & 11367 & 11449 & 0.0524 & 0.0651 \\
\hline 12 & 467.6 & 592.3 & 8784 & 9439 & 0.0532 & 0.0628 \\
\hline Year & 1056.9 & 1305.6 & 18529 & 19926 & 0.0570 & 0.0655 \\
\hline & & & & & & \\
\hline
\end{tabular}

seasons with the exception of the summer months. Larnaca shows the highest values throughout the year. As it was indicated in the section of the quality control the sensor is relatively unstable with long periods of missing records. Therefore, it requires recalibration.

\section{Frequency distribution of daily UVA irradiation}

The annual histogram of the frequency distribution $(P D F)$ of the daily UVA irradiation of both stations is displayed in figure 10, while the cumulative frequency distribution of the same variables is shown in figure 11. As indicated in figure 10, the type of the annual distribution of the daily UVA irradiation is bimodal for both stations. The PDF graphs show similarities with the highest frequencies occurring at around $600 \mathrm{~kJ} \mathrm{~m}^{-2}$ of UVA irradiation at both stations and a second highest in the range of $1500-1800 \mathrm{~kJ} \mathrm{~m}^{-2}$. Figure 11, indicates that in $60 \%$ of the year, the daily sums of UVA irradiation at Athalassa are below $1250 \mathrm{~kJ} \mathrm{~m}^{-2}$, while at Larnaca for the same value the probability is about $50 \%$.

Table 7: a) Relationships between hourly $\mathrm{UVA}_{\mathrm{h}}$ irradiance $\left(\mathrm{W} \mathrm{m}^{-2}\right)$ and global $\left(G_{h}\right)$ irradiance $\left(\mathrm{W} \mathrm{m}^{-2}\right)$ at both stations. b) Relationships between daily UVA irradiation $\left(\mathrm{kJ} \mathrm{m}^{-2}\right)$ and Global $\left(G_{d}\right)\left(\mathrm{MJ} \mathrm{m}^{-2}\right)$ irradiation at both stations.

\begin{tabular}{|l|l|l|c|}
\hline Variable $y$ & Variable $x$ & Equation & $R 2 / S$ \\
\hline UVAh_Ath & Gh_Ath & $y=0.057 x$ & 0.98 \\
\hline UVAh_Lca & Gh_Lca & $y=0.0667 x$ & 0.98 \\
\hline UVAh_Ath & Gh_Ath & $y=0.031 x^{1.093}$ & $\mathrm{~S}=2.364$ \\
\hline UVAh_Lca & Gh_Lca & $y=0.036 x^{1.092}$ & $\mathrm{~S}=2.789$ \\
\hline UVAd_Ath & Gd_Ath & $y=57.266 x$ & 0.96 \\
\hline UVAd_Lca & Gd_Lca & $y=66.202 x$ & 0.98 \\
\hline UVAd_Ath & Gd_Ath & $y=46.537 x^{1.066}$ & $\mathrm{~S}=53.29$ \\
\hline UVAd_Lca & Gd_Lca & $y=56.636 x^{1.049}$ & $\mathrm{~S}=62.21$ \\
\hline
\end{tabular}

\section{Relationship between UVA and other radiation components}

It can be useful to estimate UVA irradiance based on the global irradiance ranges. The correlation between the data have been analysed by assuming relations of the following forms:

$$
\begin{aligned}
& Y=a X \\
& Y=a X^{b}
\end{aligned}
$$

Table 7 shows the values of the fit parameters for Equations (4) and (5) as well as the coefficient of determination, $R^{2}$, for the hourly $\left(\mathrm{W} \mathrm{m}^{-2}\right)$ and daily values $\left(\mathrm{kJ} \mathrm{m}^{-2}\right)$ for both stations. The characteristic of these relationships is that the coefficients of determination are close to 1. For the model of the Equation (5) the fit of the result is given by the parameter $S$ which is the standard error of the regression. $S$ is measured in the units of the response variable and represents the standard distance the data values fall the regression line, or the standard deviation of the residuals. For a given study, the better the equation predicts the response, the lower the value of $S$. From the table $7 \mathrm{a}$, it is indicated that the results are satisfactory for estimating UVA using both the above equations. Figure 12 shows the relationship between UVA irradiance and global irradiance based on the Equation (5) for Athalassa. Similar results were obtained for the estimation of
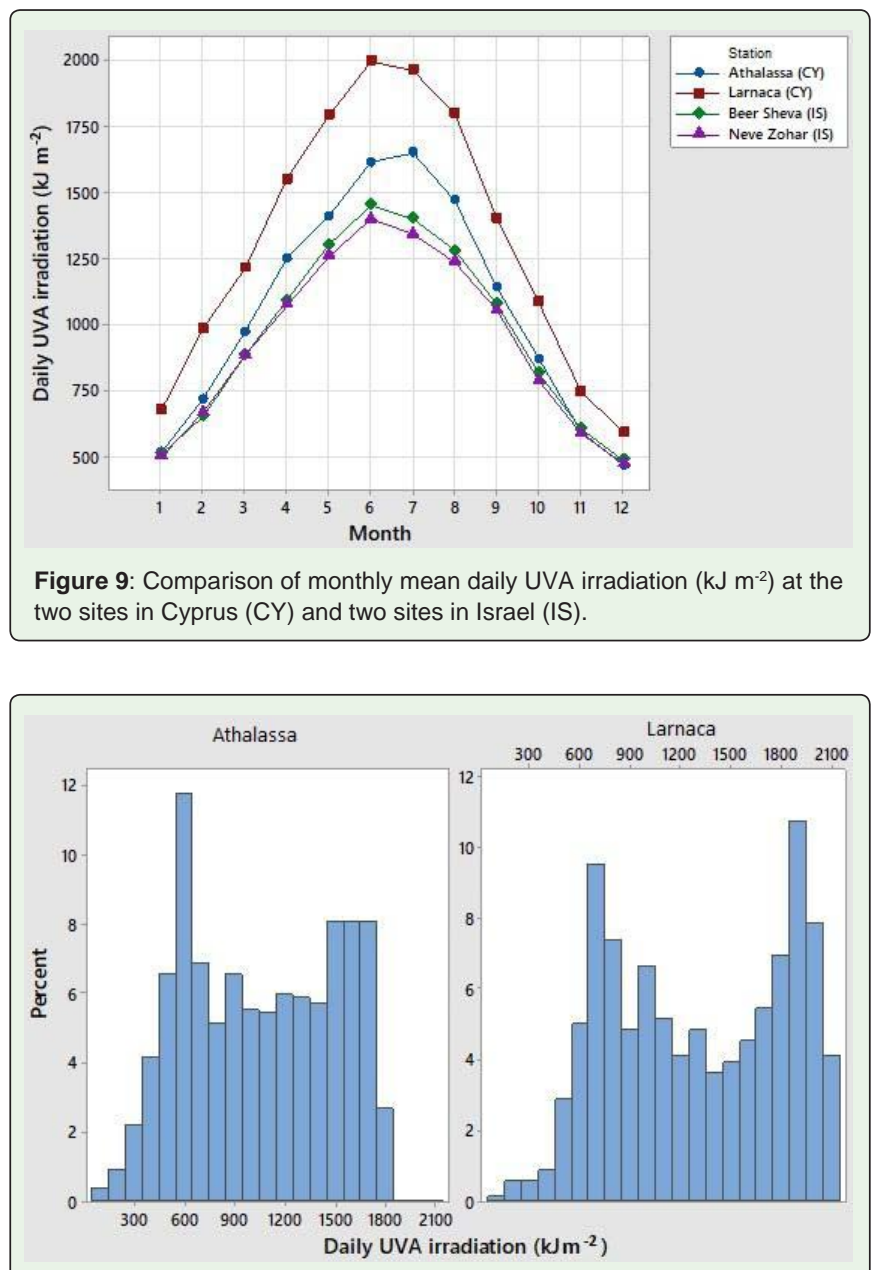

Figure 10: Annual histogram of the frequency distribution of the daily UVA irradiation $\left(\mathrm{kJ} \mathrm{m}^{-2}\right)$ at a) Athalassa and b) Larnaca. 
Table 8: Statistics of daily UVA irradiation $\left(\mathrm{kJ} \mathrm{m}^{-2}\right)$ based on various thresholds of daily global radiation $\left(\mathrm{MJ} \mathrm{m}^{-2}\right)$ for the period of measurements, for a) Athalassa and b) Larnaca.

a) Athalassa

\begin{tabular}{|c|c|c|c|c|c|c|c|}
\hline \multirow{2}{*}{\multicolumn{2}{|c|}{$\begin{array}{l}\text { Athalassa-Daily Global Radiation } \\
\text { Bin Endpoints (MJ m-2) }\end{array}$}} & \multicolumn{6}{|c|}{ Athalassa-Daily UVA radiation $\left(\mathrm{kJ} \mathrm{m}^{-2}\right)$} \\
\hline & & \multirow[t]{2}{*}{ Occurrences } & \multirow[t]{2}{*}{ Mean } & \multirow[t]{2}{*}{ Median } & \multirow[t]{2}{*}{ Min } & \multirow[t]{2}{*}{$\operatorname{Max}$} & \multirow[t]{2}{*}{ Std. Dev } \\
\hline Lower & Upper & & & & & & \\
\hline 0 & 2 & 4 & 120.2 & 116.4 & 106.5 & 146.1 & 17.73 \\
\hline 2 & 4 & 14 & 227.8 & 211.1 & 180.1 & 321.7 & 39.97 \\
\hline 6 & 8 & 41 & 414.9 & 416.0 & 336.9 & 469.6 & 32.29 \\
\hline 8 & 10 & 59 & 507.6 & 501.8 & 442.8 & 628.5 & 38.31 \\
\hline 10 & 12 & 119 & 600.6 & 585.7 & 509.6 & 756.7 & 52.09 \\
\hline 12 & 14 & 90 & 687.6 & 686.0 & 571.5 & 899.4 & 59.05 \\
\hline 14 & 16 & 72 & 820.5 & 826.0 & 590.0 & 975.8 & 66.77 \\
\hline 16 & 18 & 81 & 947.3 & 945.7 & 756.3 & 1131.9 & 67.40 \\
\hline 18 & 20 & 64 & 1053.4 & 1058.3 & 859.4 & 1185.8 & 69.19 \\
\hline 20 & 22 & 76 & 1193.1 & 1208.5 & 997.0 & 1349.2 & 70.29 \\
\hline 22 & 24 & 79 & 1318.4 & 1313.9 & 1184.1 & 1487.7 & 75.14 \\
\hline 24 & 26 & 91 & 1445.8 & 1458.2 & 1277.9 & 1581.3 & 67.59 \\
\hline 26 & 28 & 110 & 1577.2 & 1583.1 & 1433.0 & 1693.9 & 57.48 \\
\hline 28 & 30 & 106 & 1688.2 & 1696.8 & 1497.0 & 1783.8 & 52.77 \\
\hline 30 & 32 & 18 & 1769.5 & 1774.4 & 1725.9 & 1796.8 & 18.55 \\
\hline
\end{tabular}

b) Larnaca

\begin{tabular}{|c|c|c|c|c|c|c|c|}
\hline \multirow{2}{*}{\multicolumn{2}{|c|}{$\begin{array}{l}\text { Larnaca-Daily Global Radiation } \\
\left.\text { Bin Endpoints ( } \mathrm{MJ} \mathrm{m}^{-2}\right)\end{array}$}} & \multicolumn{6}{|c|}{ Larnaca-Daily UVA radiation $\left(\mathrm{kJ} \mathrm{m}^{-2}\right)$} \\
\hline & & \multirow[t]{2}{*}{ Occurrences } & \multirow[t]{2}{*}{ Mean } & \multirow[t]{2}{*}{ Median } & \multirow[t]{2}{*}{ Min } & \multirow[t]{2}{*}{$\operatorname{Max}$} & \multirow[t]{2}{*}{ Std. Dev. } \\
\hline Lower & Upper & & & & & & \\
\hline 0 & 2 & 2 & 153.4 & 182.1 & 124.6 & 182.1 & 40.66 \\
\hline 2 & 4 & 6 & 261.0 & 263.8 & 206.6 & 331.2 & 57.17 \\
\hline 4 & 6 & 4 & 393.4 & 408.3 & 343.0 & 422.2 & 34.82 \\
\hline 6 & 8 & 25 & 510.8 & 497.2 & 445.0 & 621.3 & 47.36 \\
\hline 8 & 10 & 28 & 605.1 & 596.3 & 542.9 & 701.2 & 41.92 \\
\hline 10 & 12 & 63 & 709.8 & 706.6 & 602.6 & 871.7 & 48.82 \\
\hline 12 & 14 & 68 & 811.8 & 799.6 & 555.3 & 996.6 & 75.66 \\
\hline 14 & 16 & 43 & 967.7 & 967.1 & 852.7 & 1064.2 & 50.95 \\
\hline 18 & 20 & 42 & 1219.4 & 1221.4 & 872.2 & 1372.7 & 92.86 \\
\hline 20 & 22 & 43 & 1368.6 & 1364.0 & 1182.9 & 1501.5 & 82.75 \\
\hline 22 & 24 & 29 & 1506.5 & 1501.4 & 1348.0 & 1660.6 & 77.52 \\
\hline 24 & 26 & 53 & 1651.2 & 1650.2 & 1518.6 & 1849.0 & 67.03 \\
\hline 26 & 28 & 76 & 1818.1 & 1820.3 & 1650.3 & 1955.1 & 65.98 \\
\hline 28 & 30 & 84 & 1950.2 & 1949.3 & 1821.3 & 2052.4 & 60.51 \\
\hline 30 & 32 & 44 & 2041.9 & 2057.1 & 1916.2 & 2140.2 & 56.68 \\
\hline
\end{tabular}




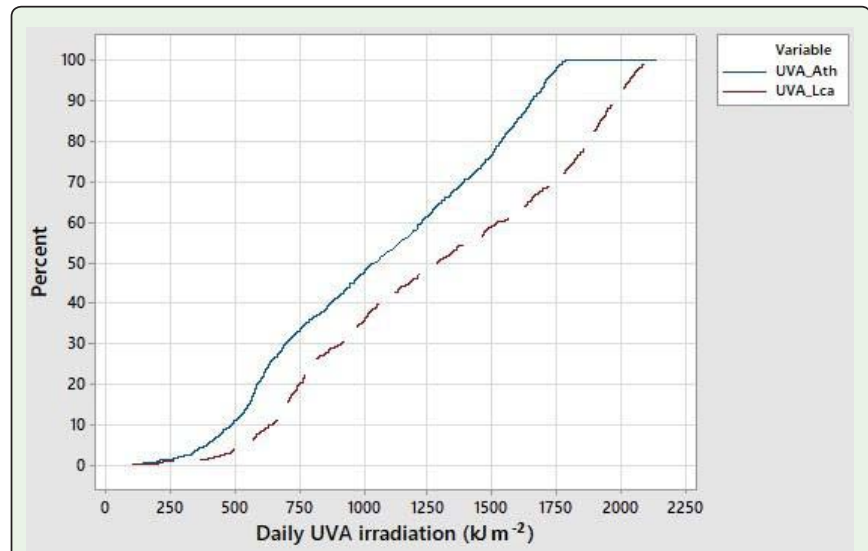

Figure 11: Annual cumulative frequency distribution of daily UVA irradiation at both stations.

the daily values of UVA (Table 7b). Generally, the constants of the equations of the two stations are comparable.

The relationships of the UVA variables between the two stations are shown below. The coefficient of determination is high for both relations.

Hourly data $\left(\mathrm{W} \mathrm{m}^{-2}\right)$ :

$$
U V A_{h-} \text { Ath }=1.023+0.778 U V A_{h \_} L c a R^{2}=0.91
$$

Daily data $\left(\mathrm{kJ} \mathrm{m}^{-2}\right)$ :

$$
U V A_{d} \text { A Ath }=-25.35+0.830 U V A_{d} \text { L Lca } R^{2}=0.95
$$

It is also interesting to know the statistics of the daily UVA radiation obtained from different daily global radiation thresholds, since most of the stations measure global radiation. Table 8 presents the results of the above classification. At Athalassa, the most frequent cases occurred in the bins of 10-12 ( $\left.\mathrm{MJ} \mathrm{m}^{-2}\right)$ of daily global irradiation following by the bins of 26-28 and 28-30 $\left(\mathrm{MJ} \mathrm{m}^{-2}\right)$. At Larnaca, the values of both global and UVA irradiation are higher and the most frequent cases occurred in the bins of 10-12 and 12-14 (MJ $\left.\mathrm{m}^{-2}\right)$ of daily global irradiation following by the bins of 26-28 and 28-30 (MJ $\mathrm{m}^{-2}$ ). The mean and the median values of UVA irradiation are almost similar at both stations. It is estimated that UVA irradiation is about

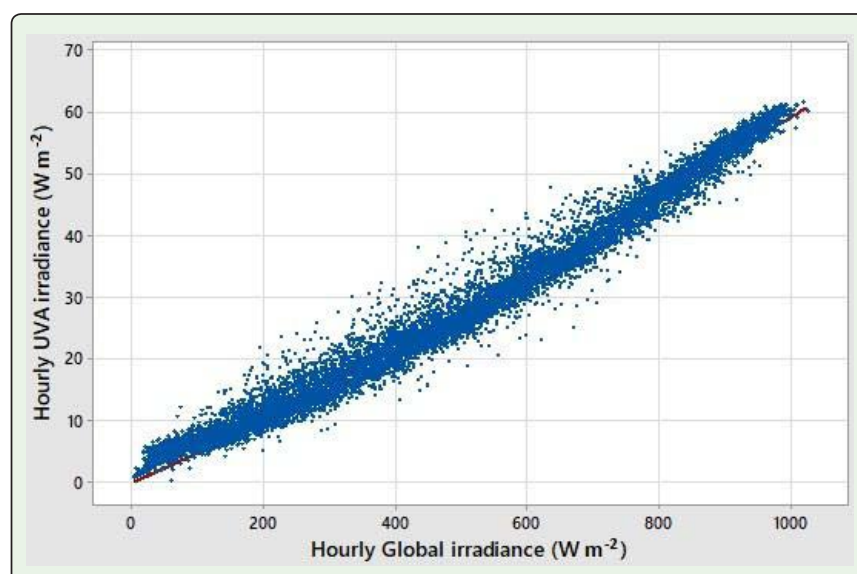

Figure 12: Relationship of hourly UVA and global irradiances based on Equation (5) at Athalassa.
$5.7 \%$ of global irradiation at Athalassa (inland location) and about $6.7 \%$ at Larnaca (coastal location).

\section{Relationships between hemispherical transmittances}

In this section the relationships between the clearness index (global hemispherical transmittance) $\left(k_{t}\right)$ and the UVA hemispherical transmittance $\left(\mathrm{k}_{\mathrm{UVA}}\right)$ will be examined. The clearness index is defined as: $k_{t}=G / G_{0}, G$ being the measured global irradiance and $G_{0}$ the extraterrestrial solar irradiance, both measured on horizontal surface and for the same interval of time [5]. In the same way the UVA hemispherical transmittance $\left(k_{U V A}\right)$ is defined as: $k_{U V A}=U V A / U V A_{0}$, where UVA is the measured irradiance and $U V A_{0}$ is the extraterrestrial UVA irradiance, both measured on a horizontal surface during the same time interval. The small ' $\mathrm{k}$ ' refers to hourly values, while the capital letter ' $K$ ' denotes daily values. The daily extraterrestrial $\left(U V A_{d 0}\right)$ irradiation is estimated from the following equation:

$$
U V A_{d 0}=(24 / \pi)^{*} \varepsilon^{*} G_{s c U V A}\left[\sin \phi \sin \delta\left(\left(\pi \omega_{s}\right) / 180\right)+\cos \phi \cos \delta \sin \omega_{s}\right]
$$

Where $\varepsilon$ is the eccentricity, $\varphi$ is the latitude, $\delta$ is the solar declination, $\omega_{s}$ is the sunset hour angle and $G_{s c U V A}$ is the UVA solar constant $\left(70.64 \mathrm{~W} \mathrm{~m}^{-2}\right)$ and it was obtained from Gueymard [41].

Figure 13 shows the histograms with the hourly values of $k_{t}$. Most of the data are concentrated in the 0.7-0.8 range at both stations. The clearness index is mostly affected by the presence of clouds. Figure 14 shows the histograms with the hourly values of $k_{U V A}$. Most of the data are concentrated in the 0.4-0.8 range at both stations.
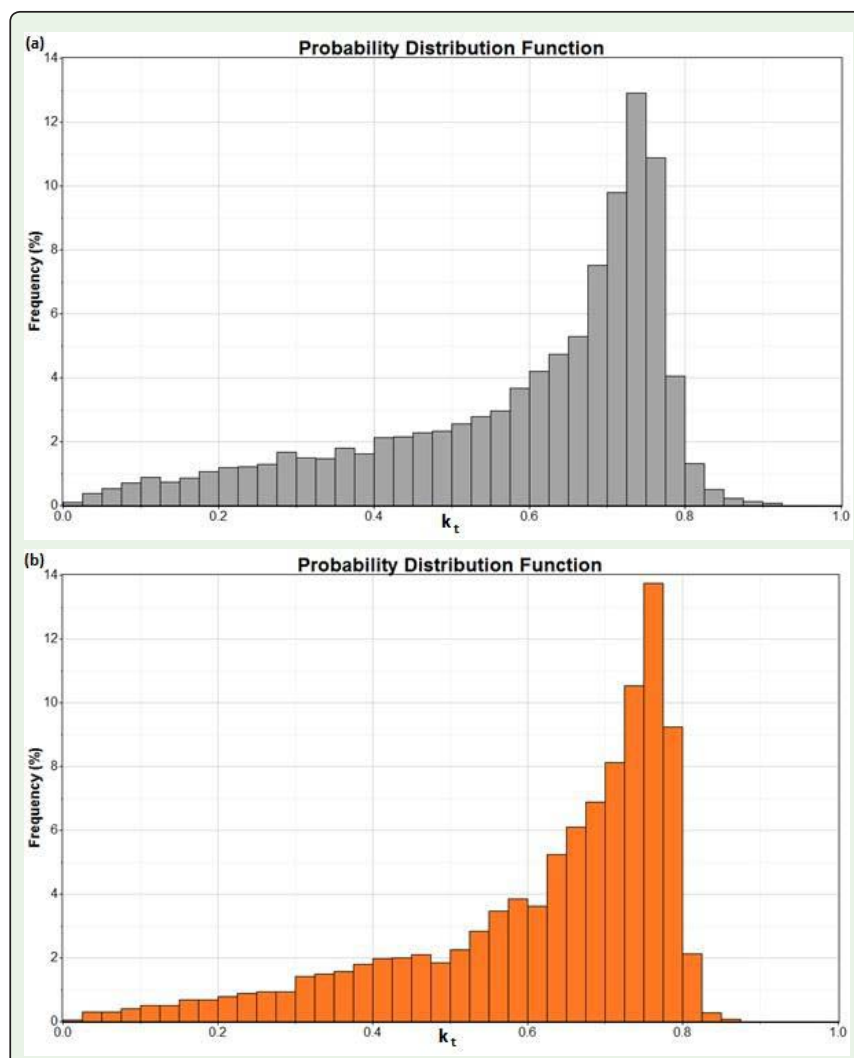

Figure 13: Frequency distribution of hourly clearness index $\left(k_{t}\right)$ at a) Athalassa and b) Larnaca. 
The above results suggest that relationships can be established between the indexes $k_{t}$ and $k_{U V A}$. Two different models were implemented. Firstly, a linear fit was applied, without intercept of the form: $k_{U V A}=a k_{t}$. Secondly, a model of the form of Equation (5) was applied. The above models were applied for both the hourly and daily values of the said transmittances (Table 9). As it is indicated from the constant of the linear fit, the hemispherical transmittance $k_{U V A}$ is approximately 6 to $7 \%$ of the hemispherical transmittance for the whole spectrum $\left(k_{t}\right)$. In the case of the linear regression, the coefficient of determination $\left(R^{2}\right)$ is 0.97 for the hourly values and 0.99 for the daily values, suggesting that the linear fit is better than the other models. The standard error of the regression $(S)$ of the third model is also low which suggests that the model could be also used for the prediction of the $k_{U V A}$ transmittance. Generally, the values of the constants of the three models of the two stations are comparable.

Table 10 shows the levels of the daily UVA irradiation based on the classification of the daily clearness index $\left(\mathrm{K}_{\mathrm{T}}\right)$, i.e., $\mathrm{K}_{\mathrm{T}}>0.65$ clear days, $0.35<\mathrm{K}_{\mathrm{T}} \leq 0.65$ partly cloudy days and $\mathrm{K}_{\mathrm{T}}<0.35$ cloudy days. The median values of the daily UVA irradiation at Athalassa, are lower than the mean values for the cases of cloudy and partly cloudy days, while for the clear days they are higher. At Larnaca, the median values on cloudy days are slightly higher than the mean values, reversing during partly cloudy days and again higher during the clear days.

\section{Attenuation of the UVA radiation}
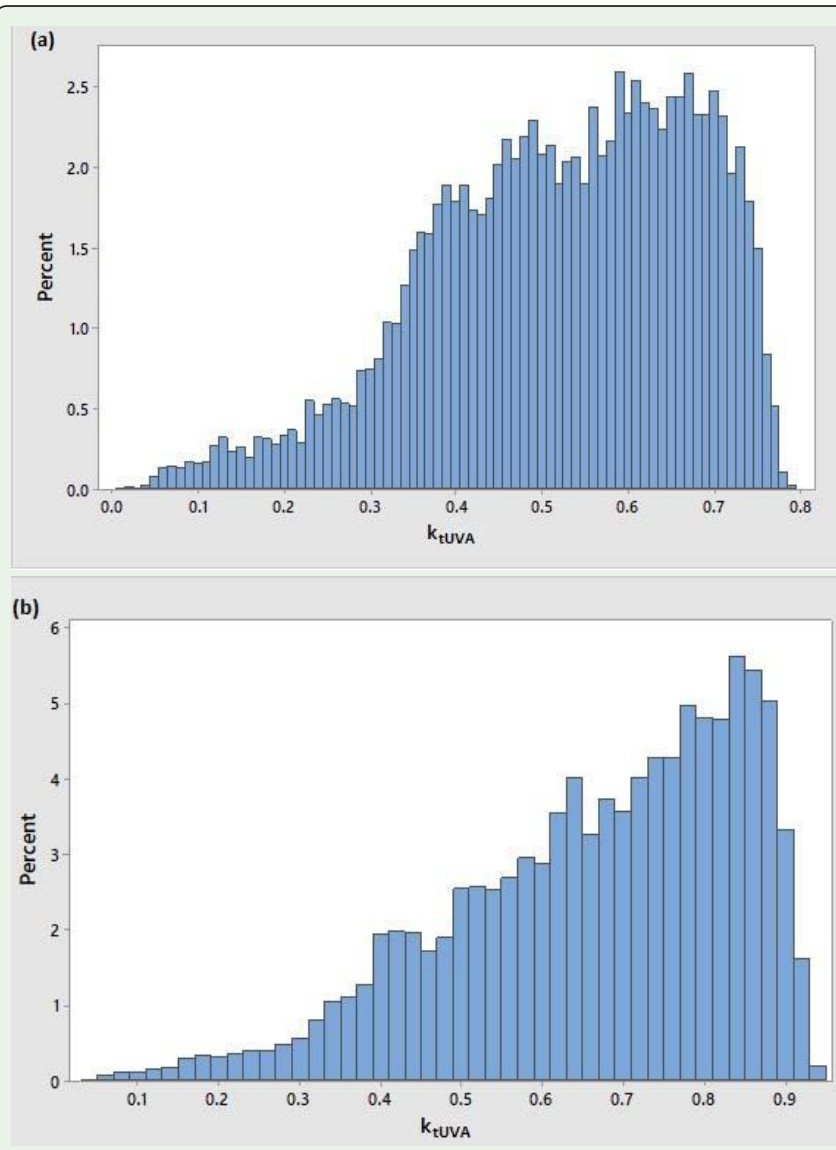

Figure 14: Frequency distribution of hourly UVA hemispherical transmittance $\left(k_{u V A}\right)$ at a) Athalassa and b) Larnaca.
Table 9a: Relationships between hourly transmittance $k_{u V A}$ of UVA irradiance and the clearness index $\left(k_{t}\right)$ of global irradiance $\left(\mathrm{W} \mathrm{m}^{-2}\right)$ at both stations.

\begin{tabular}{|l|c|c|c|}
\hline Variable $y$ & Variable $\boldsymbol{x}$ & Equation & R2 / S \\
\hline kUVA_Ath & kt_Ath & $y=0.881 x$ & 0.97 \\
\hline kUVA_Lca & $k t \_L c a$ & $y=1.033 x$ & 0.97 \\
\hline kUVA_Ath & $k$ kt_Ath & $y=0.766 x^{0.655}$ & $S=0.083$ \\
\hline kUVA_Lca & $k$ k_Lca & $y=0.932 x^{0.720}$ & $S=0.116$ \\
\hline
\end{tabular}

Table 9b: Relationships between the daily transmittance $\left(K_{U V A}\right)$ and the daily transmittance $\left(K_{T}\right)$ at both stations.

\begin{tabular}{|c|c|c|c|}
\hline Variable $y$ & Variable $x$ & Equation & R2 IS \\
\hline KUVA_Ath & KT_Ath & $y=0.549 x$ & 0.99 \\
\hline KUVA_Lca & KT_Lca & $y=1.406 x$ & 0.99 \\
\hline KUVA_Ath & KT_Ath & $y=0.536 x^{0.945}$ & $S=0.029$ \\
\hline KUVA_Lca & $K T \_L c a$ & $y=1.261 x^{0.771}$ & $S=0.046$ \\
\hline
\end{tabular}

The daily UVA irradiation during the clear days is the highest expected on the Earth's surface and is defined as the potential UVA irradiation $\left(U V A_{p}\right)$. From the monthly mean daily values of UVA potential $\left(U V A_{p}\right)^{p}$, extraterrestrial $\left(U V A_{0}\right)$ and measured (UVA) radiation, the ratios between these variables were estimated. The ratio $U V A / U V A_{p}$ represents information about the percentage of energy which, on the average, is transmitted by the atmosphere and may be considered as the atmospheric transparency under average conditions, i.e., including hydrometeors and aerosols. The ratio of UVA potential to UVA extraterrestrial, $U V A_{p} / U V A_{0}$, gives information about the atmospheric transparency on clear days, i.e, without clouds but with aerosols, though in low proportion. The ratio of $U V A / U V A_{p}$, represents the observed UVA irradiation fraction which corresponds to cloud-free sky, i.e., this attenuation is due to cloudiness and aerosols [42-43].

Figure 15 shows the monthly average daily values of extraterrestrial $\left(U V A_{0}\right)$, the potential $\left(U V A_{p}\right)$ and measured $U V A$ irradiation at Athalassa. The graph shows that the maximum of $\left(U V A_{0}\right)$ and $\left(U V A_{p}\right)$ variables is recorded in June, but the maximum of the measured UVA is recorded in July. The difference between the UVA and UVA measured values is greater in the spring and winter time, while during the summer the difference is small. This is attributed to the fact that during the summer almost all days are clear [33].

Figure 16 shows the monthly mean of the above ratios for Athalassa. The greatest variability is shown in the ratio of UVA/UVA. The evolution of these ratios increases from spring to summer and decreases from summer to winter. The maximum of $U V A / U V A_{0}$ is 0.9 , while the ratio $U V A / U V A_{p}$ is close to one in the summer.

\section{Inter-Comparison of the Two Sites}

The inter-comparison of the broad-band solar radiation intensity measurements at both sites are reported in table 11 for the global, UVB and UVA radiation. The solar radiation intensities are reported as monthly average daily values, the number of days of each variable for the period of measurements and the relative attenuation reported for each one, which is defined as: 
Table 10: Statistics of daily UVA irradiation $\left(\mathrm{kJ} \mathrm{m}^{-2}\right)$ based on various thresholds of daily clearness index ( $\left.\mathrm{K}_{\mathrm{T}}\right)$ for the period of measurements, for a) Athalassa and b) Larnaca.

a) Athalassa

\begin{tabular}{|c|c|c|c|c|c|c|c|}
\hline \multicolumn{2}{|c|}{$\mathrm{K}_{\mathrm{T}}$ Bin Endpoints } & \multirow[t]{2}{*}{ Occurrences } & \multicolumn{5}{|c|}{ Daily UVA irradiation $\left(\mathrm{kJ} \mathrm{m}^{-2}\right)$} \\
\hline Lower & Upper & & Mean & Median & Min & Max & Std. Dev. \\
\hline 0 & 0.05 & 0 & & & & & \\
\hline 0.05 & 0.1 & 5 & 160.5 & 116.4 & 106.5 & 321.7 & 91.4 \\
\hline 0.1 & 0.15 & 4 & 231.5 & 211.1 & 180.1 & 332.7 & 68.7 \\
\hline 0.15 & 0.2 & 6 & 212.2 & 209.4 & 197.4 & 243.1 & 16.5 \\
\hline 0.2 & 0.25 & 10 & 337.8 & 363.5 & 197.9 & 439.2 & 83.2 \\
\hline 0.25 & 0.3 & 20 & 401.9 & 348.8 & 276.9 & 735.1 & 136.5 \\
\hline 0.3 & 0.35 & 18 & 463.3 & 424.5 & 297.5 & 842.0 & 158.4 \\
\hline 0.35 & 0.4 & 35 & 557.4 & 538.2 & 336.9 & 975.8 & 183.4 \\
\hline 0.4 & 0.45 & 38 & 702.4 & 672.2 & 401.4 & 1157.4 & 238.4 \\
\hline 0.45 & 0.5 & 53 & 716.6 & 688.2 & 398.6 & 1261.9 & 226.2 \\
\hline 0.5 & 0.55 & 71 & 765.3 & 613.4 & 442.8 & 1378.5 & 298.1 \\
\hline 0.55 & 0.6 & 103 & 919.1 & 898.3 & 481.7 & 1508.9 & 297.6 \\
\hline 0.6 & 0.65 & 145 & 1039.6 & 1071.4 & 509.6 & 1590.2 & 343.2 \\
\hline 0.65 & 0.7 & 328 & 1226.9 & 1369.6 & 534.4 & 1741.2 & 392.4 \\
\hline 0.7 & 0.75 & 210 & 1390.8 & 1526.0 & 571.9 & 1796.8 & 353.1 \\
\hline 0.75 & 0.8 & 3 & 1691.7 & 1751.0 & 1564.1 & 1760.0 & 110.6 \\
\hline
\end{tabular}

b) Larnaca

\begin{tabular}{|c|c|c|c|c|c|c|c|}
\hline \multicolumn{2}{|c|}{$\mathrm{K}_{\mathrm{T}}$ Bin Endpoints } & \multirow[t]{2}{*}{ Occurrences } & \multicolumn{5}{|c|}{ Daily UVA irradiation $\left(\mathrm{kJ} \mathrm{m}^{-2}\right)$} \\
\hline Lower & Upper & & Mean & Median & Min & Max & Std. Dev. \\
\hline 0 & 0.05 & 0 & & & & & \\
\hline 0.05 & 0.1 & 1 & 124.6 & 124.6 & 124.6 & 124.6 & 0.0 \\
\hline 0.1 & 0.15 & 4 & 206.0 & 211.6 & 182.1 & 223.8 & 17.5 \\
\hline 0.15 & 0.2 & 3 & 308.0 & 329.0 & 263.8 & 331.2 & 38.3 \\
\hline 0.2 & 0.25 & 3 & 481.7 & 445.0 & 343.0 & 657.1 & 160.3 \\
\hline 0.25 & 0.3 & 3 & 643.3 & 583.3 & 540.2 & 806.3 & 142.8 \\
\hline 0.3 & 0.35 & 9 & 511.6 & 492.4 & 400.1 & 701.2 & 103.3 \\
\hline 0.35 & 0.4 & 11 & 567.9 & 507.9 & 447.1 & 834.9 & 141.4 \\
\hline 0.4 & 0.45 & 17 & 675.9 & 595.6 & 455.9 & 1256.1 & 212.9 \\
\hline 0.45 & 0.5 & 24 & 798.1 & 745.7 & 489.8 & 1335.8 & 273.8 \\
\hline 0.5 & 0.55 & 34 & 922.7 & 934.3 & 542.9 & 1479.7 & 265.2 \\
\hline 0.55 & 0.6 & 44 & 979.4 & 918.0 & 576.7 & 1660.6 & 332.6 \\
\hline 0.6 & 0.65 & 62 & 1057.4 & 976.6 & 602.6 & 1866.5 & 365.0 \\
\hline 0.65 & 0.7 & 132 & 1273.9 & 1288.9 & 627.4 & 1995.7 & 454.1 \\
\hline 0.7 & 0.75 & 273 & 1613.0 & 1774.0 & 647.7 & 2120.2 & 416.3 \\
\hline 0.75 & 0.8 & 40 & 1660.3 & 1768.4 & 967.2 & 2140.2 & 335.0 \\
\hline
\end{tabular}

RelativeAttenuation(\%) $=\left(\left(X_{L c a}-X_{A t h}\right) / X_{A t h}\right) * 100$

where $X$ refers the type of solar radiation, i.e., either global, UVB or UVA. The subscripts refer to the two sites.

As indicated in table 11, the magnitudes of the monthly average daily values of the three types of solar radiation components are higher at Larnaca than at Athalassa. Generally, the percentages of relative attenuation are lower during the summer period for all the three variables. The $\%$ relative attenuation is $<10 \%$ for all months. The differences in altitude between the two stations are not significant and therefore the daily values are almost similar. However, the percentage of relative attenuation of UVB is higher than that of UVA since the 
Table 11: Monthly average daily solar global, UVB and UVA at Athalassa and Larnaca and their relative differences.

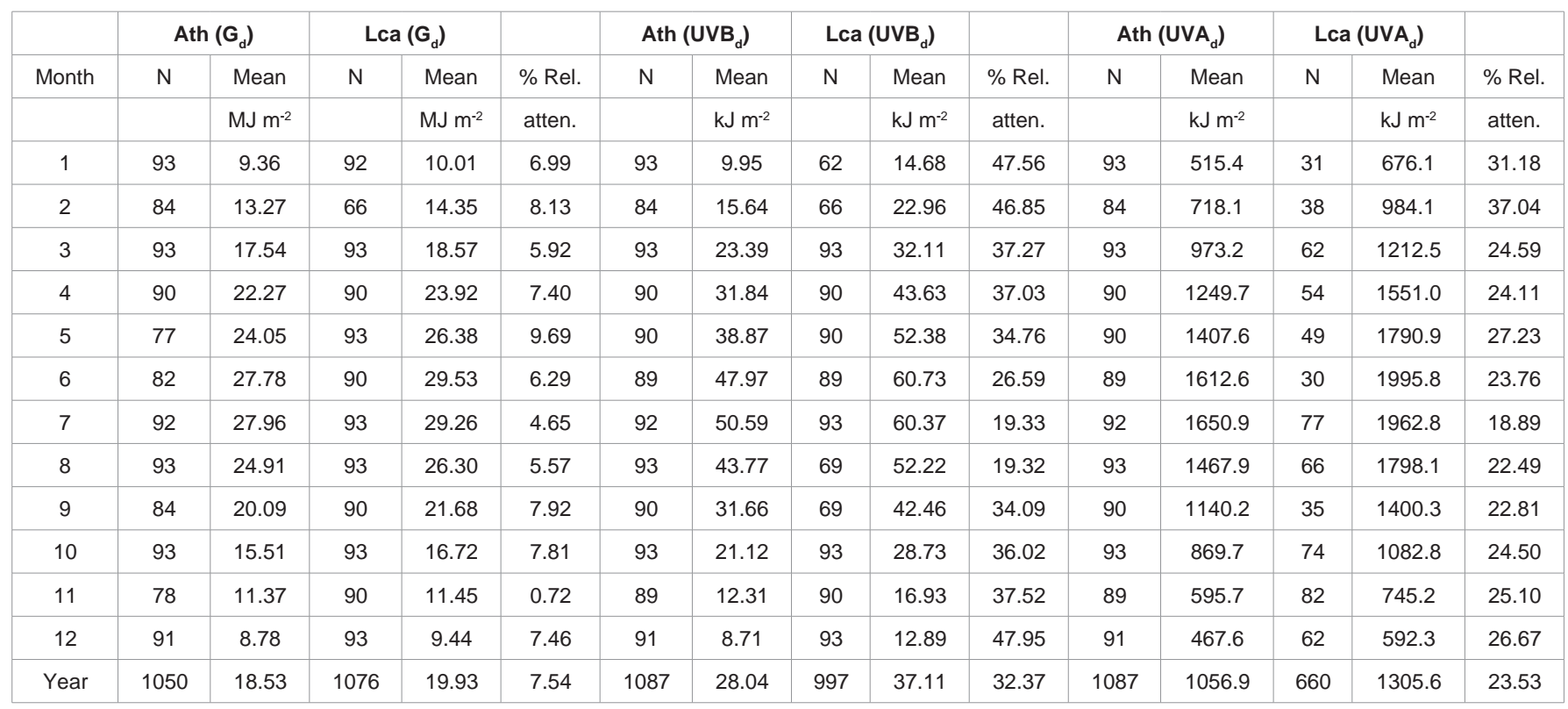
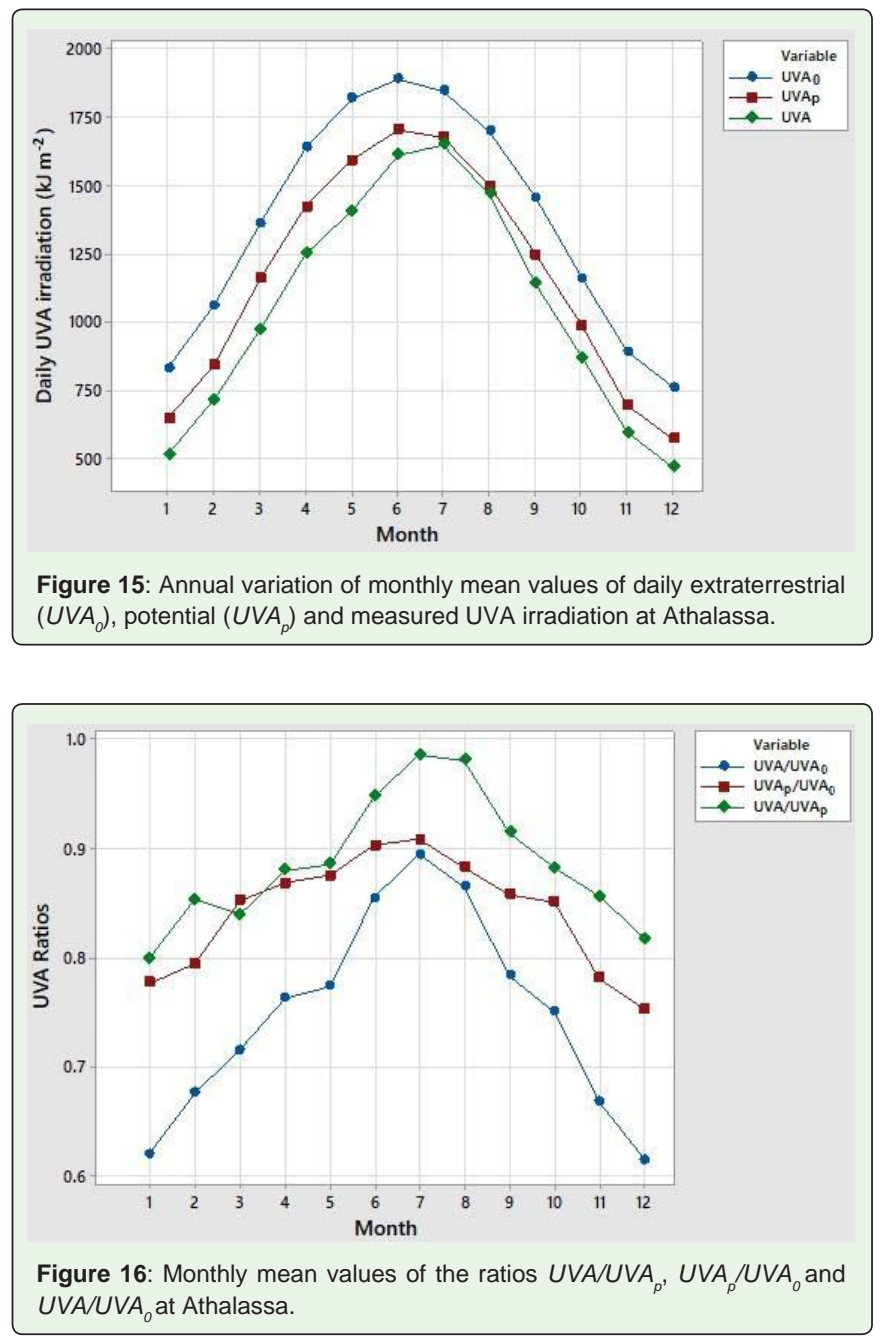

Table 12: Inter-comparison of the two sites with respect to global and UVA radiation.

\begin{tabular}{|c|c|c|}
\hline Variable & Athalassa & Larnaca \\
\hline Location & inland & coastal \\
\hline Annual daily average global irradiation $(\mathrm{Gd})\left(\mathrm{MJ} \mathrm{m}^{-2}\right)$ & 18.53 & 19.93 \\
\hline Annual total global irradiation $\left(\mathrm{MJ} \mathrm{m}^{-2}\right)$ & 6835 & 7183 \\
\hline Annual daily average UVA irradiation (UVAd) $\left(\mathrm{kJ} \mathrm{m}^{-2}\right)$ & 1056 & 1316 \\
\hline Annual total UVA irradiation $\left(\mathrm{MJ} \mathrm{m}^{-2}\right)$ & 12.74 & 15.95 \\
\hline Accumulated daily UVA irradiation in July $\left(\mathrm{kJ} \mathrm{m}^{-2}\right)$ & 1650.8 & 2000.9 \\
\hline Accumulated daily UVA irradiation in December $\left(\mathrm{kJ} \mathrm{m}^{-2}\right)$ & 467.5 & 609.4 \\
\hline Mean annual daily ratio of UVA/G & 0.0569 & 0.0661 \\
\hline $\begin{array}{l}\text { Maximum Hourly Average UVA irradiance in July (W } \\
\left.\qquad \mathrm{m}^{-2}\right)\end{array}$ & 61.03 & 72.78 \\
\hline $\begin{array}{l}\text { Maximum Hourly Average UVA irradiance in December } \\
\qquad\left(\mathrm{W} \mathrm{m}^{-2}\right)\end{array}$ & 29.73 & 37.02 \\
\hline Mean annual Ratio of daily UVA/UVAp & 0.886 & 0.923 \\
\hline
\end{tabular}

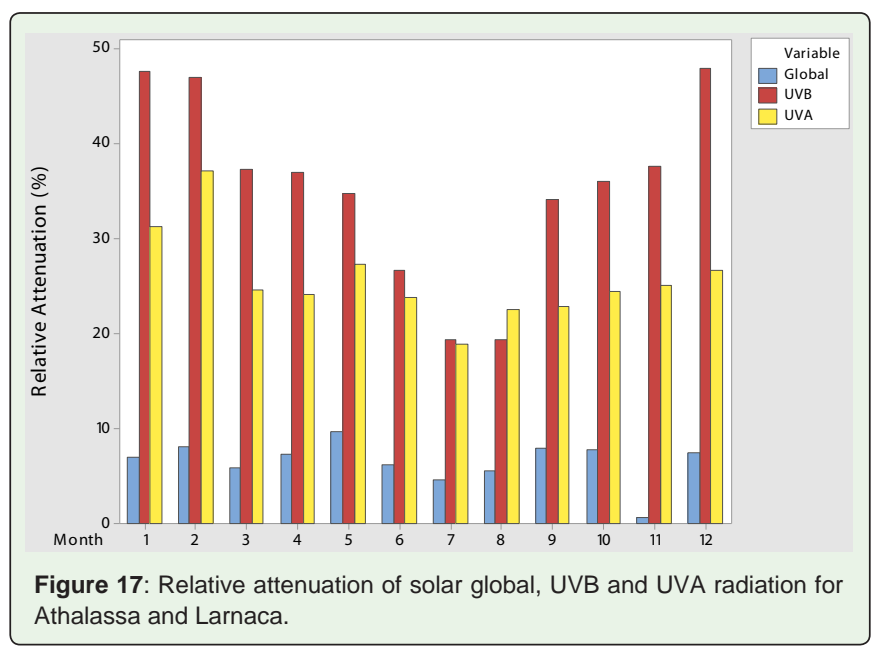


attenuation is inversely proportional to the wavelength and therefore greater for the shorter UVB wavelengths. The high values of relative attenuation of the UVA radiation could be also attributed to the fact that long periods of missing data were detected in the time series of UVA at Larnaca. The percent relative attenuation is also presented graphically for the three solar radiation types in figure 17.

The summary of the inter-comparison of the two sites with respect to UVA radiation is presented in table 12.

\section{Conclusion}

Measured data at 10 min intervals, obtained by UV Kipp\&Zonen radiometers installed at two locations in Cyprus, one at Athalassa (inland location) and the other at Larnaca (coastal location) during the period January 2013 and December 2015, have been used to define the statistical characteristics of both hourly UVA irradiance and daily UVA irradiation values.

Large fluctuations in the spring and winter months are mainly due to unstable meteorological conditions during the transition from cold to warm weather and vice versa. During summer the daily UVA radiation exceeds the value of $1700 \mathrm{~kJ} \mathrm{~m}^{-2}$ at Athalassa and $2100 \mathrm{~kJ} \mathrm{~m}^{-2}$ at Larnaca, while during the winter season the lowest maximum is about $600 \mathrm{~kJ} \mathrm{~m}^{-2}$ at Athalassa and about $770 \mathrm{~kJ} \mathrm{~m}^{-2}$ at Larnaca. Slightly lower values were recorded in the year 2015 at both stations which can be attributed to the higher amounts of aerosols in the atmosphere. The year 2015 is characterized as an extremely dry year with more frequent dust episodes over the island (dust from the deserts of Middle East and Sahara), increasing therefore the aerosols in the atmosphere which affect the absorption of the UVA radiation. The accumulated UVA irradiation received in an average year is $385.8 \mathrm{MJ} \mathrm{m}^{-2}$ for Athalassa and $476.5 \mathrm{MJ} \mathrm{m}^{-2}$ for Larnaca. UVA daily values at Athalassa are comparable with those in Israel during most of the months. Larnaca shows the highest values throughout the year. Furthermore, the distribution types of the daily UVA irradiation for each of the month of the year are similar to those in Israel. The type of the annual distribution of the daily UVA irradiation is bimodal for both stations.

The UVA variability has been studied by means of the Coefficient of Variation (CV). It was demonstrated that the CVs in July are low during the midday (3-9\%) at both stations, indicating a high stability along these hours in summer.

Regarding the hourly values, UVA irradiance fluctuates between $22 \mathrm{~W} \mathrm{~m}^{-2}$ in December and $53 \mathrm{~W} \mathrm{~m}^{-2}$ in July at solar noon at Athalassa. The values at Larnaca are slightly higher than in Athalassa and they fluctuate between $29 \mathrm{Wm}^{-2}$ in December and $69 \mathrm{~W} \mathrm{~m}^{-2}$ in July at solar noon. Solar elevation plays an important role on the levels of UVA irradiances.

With respect to the estimation of UVA irradiance, it is indicated that the results were satisfactory for estimating UVA from the global irradiance values, either using linear relationships or relations of the power form (Equation (5)). Similar results were obtained for the estimation of the daily values of UVA. Generally, the constants of the equations of the two stations are comparable.

The difference between the potential UVA $\left(U V A_{p}\right)$ and the measured UVA values is greater in the spring and winter time, while during the summer the difference is small. This is attributed to the fact that during the summer almost all days are clear.
Two different models were implemented to estimate the UVA transmittance. Firstly, a linear fit was adopted, without intercept of the form: $k_{U V A}=a k_{t}$. Secondly, a power model based of the form of Equation (5). The above models were applied to both the hourly and daily data. As it is indicated from the constant of the linear fit, the hemispherical transmittance $k_{U V A}$ is approximately 6 to $7 \%$ of the hemispherical transmittance for the whole spectrum $\left(k_{t}\right)$. In the case of the linear regression, the coefficient of determination $\left(R^{2}\right)$ is 0.97 for the hourly values and 0.99 for the daily values, suggesting that the linear fit is better than the other models.

As indicated from the analysis, the magnitudes of the monthly average daily values of the three types of solar radiation components (global, UVB and UVA) are higher at Larnaca than at Athalassa. Generally, the percentages of relative attenuation are lower during the summer period for all the three components. The \% relative attenuation is $<10 \%$ for all months. The differences in altitude between the two stations are not significant and therefore the daily values are almost similar. However, the percentage of relative attenuation of UVB is higher than that of UVA since the attenuation is inversely proportional to the wavelength and therefore greater for the shorter UVB wavelengths. The high values of relative attenuation of the UVA radiation could be also attributed to the fact that long periods of missing data were detected in the time series of UVA at Larnaca.

\section{Nomenclature}

\begin{tabular}{|c|c|}
\hline$A_{s}$ & Skewness coefficient \\
\hline$C D F$ & Cumulative probability density function \\
\hline$C V$ & Coefficient of variation (\%) \\
\hline$G$ & Global solar irradiance $\left[\mathrm{Wm}^{-2}\right]$ \\
\hline$G_{0}$ & Extraterrestrial irradiance $\left[\mathrm{Wm}^{-2}\right]$ \\
\hline$G_{0 d}$ & Daily Extraterrestrial Irradiation (ETR) $\left[\mathrm{MJ} \mathrm{m}^{-2}\right]$ \\
\hline$G_{d}$ & Daily global irradiation $\left[\mathrm{MJ} \mathrm{m}^{-2}\right]$ \\
\hline$G_{s c}$ & Solar constant $\left[1367 \mathrm{Wm}^{-2}\right]$ \\
\hline$G_{s c U V A}$ & Solar constant of UVA irradiance $\left[70.64 \mathrm{Wm}^{-2}\right]$ \\
\hline$I Q R$ & Interquartile range \\
\hline$K$ & Kurtosis \\
\hline$k_{t}$ & Hourly clearness index $\left(k_{t}=G / G_{0}\right)$ \\
\hline$k_{U V A}$ & Hourly UVA transmittance $\left(k_{U V A}=U V A / U V A_{0}\right)$ \\
\hline$K_{T}$ & Daily clearness index $\left(K_{T}=G_{d} / G_{0 d}\right)$ \\
\hline Max & Maximum \\
\hline Min & Minimum \\
\hline$N$ & Non missing observations \\
\hline $\mathrm{N}^{*}$ & Missing observations \\
\hline$n$ & Julian day number (1..365) \\
\hline$P_{5}$ & Percentile 5\% \\
\hline$P_{95}$ & Percentile 95\% \\
\hline
\end{tabular}


PDF Probability density function

Q1 First Quartile

Q3 Third Quartile

$S \quad$ Standard error of the regression or standard deviation of the residuals

StDev Standard deviation

UVC Ultraviolet radiation in the range of 100 to $280 \mathrm{~nm}$

UVB UVB irradiance $\left[\mathrm{Wm}^{-2}\right] /$ UVB irradiation $\left[\mathrm{kJm}^{-2}\right]$

UVA UVA irradiance $\left[\mathrm{Wm}^{-2}\right] /$ UVA irradiation $\left[\mathrm{kJm}^{-2}\right]$

$U V A_{0} \quad$ Extraterrestrial UVA irradiance $\left[\mathrm{Wm}^{-2}\right]$

$U V A_{p} \quad$ Potential UVA irradiance $\left[\mathrm{Wm}^{-2}\right]$

$U V A_{d} \quad$ Daily UVA irradiation $\left[\mathrm{kJ} \mathrm{m}^{-2}\right]$

$U V A_{d} \quad$ Daily UVA irradiation $\left[\mathrm{kJ} \mathrm{m}^{-2}\right]$

UVER UV erythema irradiance $\left[\mathrm{Wm}^{-2}\right] / \mathrm{UV}$ erythema irradiation $\left[\mathrm{kJ} \mathrm{m}^{-2}\right]$

UV UV irradiance $\left[\mathrm{Wm}^{-2}\right] / \mathrm{UV}$ irradiation $\left[\mathrm{kJ} \mathrm{m}^{-2}\right](\mathrm{UV}(\mathrm{A}+\mathrm{B}))$

Greek:

$\theta_{z} \quad$ Solar zenith angle (SZA) [degrees]

$\delta \quad$ Solar declination [degrees]

$\varepsilon \quad$ eccentricity correction

$\varphi \quad$ Latitude [degrees]

$\omega_{s} \quad$ Sunset hour angle [degrees]

\section{References}

1. WMO and UNEP. Executive Summary: WMO/UNEP Scientific Assessment of Ozone Depletion. Prepared by the Scientific Assessment Panel of the Montreal Protocol on Substances That Deplete the Ozone Layer. 2006.

2. Casale GR, Meloni D, Miano S, Palmieri S, Siani AM. Solar UV-B irradiance and total ozone in Italy: fluctuations and trends. J Geophys Res. 2000; 105 4895-4901.

3. Bartlett LM, Webb AR. Changes in ultraviolet radiation in the 1990s: spectral measurements from Reading, England. J Geophys Res. 2000; 105: 48894893.

4. CIE. Standardization of the terms UV-A1, UV-A2 and UV-B. Vienna: CIE, Report CIE-134/1. 1999.

5. Iqbal M. 1983. An Introduction to Solar radiation. Academic Press, New York. 1983.

6. WHO. Global Solar UV Index. 2002.

7. Coldiron B. The UV Index: A weather report for skin. Clin Dermatol. 1998; 16: $441-446$

8. Diffey B. Solar ultraviolet effects on biological systems. Physics in Medicine and Biology. 1991; 36: 299-328.

9. MacKie R. Long-term health risk to the skin of ultraviolet radiation. Prog Biophys Mol Bio. 2006; 92: 92-96.

10. Diffey B. The consistency of studies of ultraviolet erythema in normal human skin. Phys Med Biol. 1982; 27: 715-720.
11. Fioletov E, McArthur E, Mathews T, Marrett L. On the relationship between erythemal and vitamin $D$ action spectrum weighted ultraviolet radiation. Journal of Photochemistry and Photobiology B: Biology. 2009; 95: 9-16.

12. Heisler CM, Grant RE. Ultraviolet radiation in urban ecosystems with consideration of effects on human health. Urban Ecosys. 2000; 4: 193-229.

13. Poon TS, Barnetson RS, Halliday GM. Prevention of immunosuppression by sunscreensinhumansisunrelatedto protection from erythema and dependent on protection from ultraviolet $A$ in the face of constant ultraviolet $B$ protection. J Invest Dermatol. 2003; 121: 184-190.

14. Zerefos C, Meleti C, Lambros A. The recent UV variability over south-eastern Europe. Journal of Photochemistry and Photobiology. 1995; 20: 15-19.

15. Bilbao J, Gonzalez P, Miguel A. UV-B climatology in Central Spain. International Journal of Climatology. 2008; 28: 1933-1941.

16. Utrillas M, Marín M, Esteve A, Estellés V, Gandía S, Núnez J. Ten years of measured UV Index from the Spanish UVB Radiometric Network. Journal of Photoch and Photob B: Biology. 2013; 125: 1-7.

17. Kudish A, Lyubanksky V, Evseev E, lanetz A. Statistical analysis and intercomparison of the solar UVB, UVA and global radiation for Beer Sheva and Neve Zohar (Dead Sea), Israel. Ther Appl Climatol. 2005; 80: 1-15.

18. Robaa SM. A study of ultraviolet solar radiation at Cairo urban area, Egypt. Solar Energy. 2004; 77: 251-259.

19. Jacovides C, Assimakopoulos V, Tymvios F, Theophilou K, Assimakopoulos D. Solar global UV (280-380 $\mathrm{nm})$ radiation and its relationship with solar global radiation measured on the island of Cyprus. Energy. 2006; 31: 27282738.

20. Jacovides C, Tymvios F, Assimakopoulos D, Kaltsunides N, Theocharatos G, Tsitouri M. Solar UVB $(280-315 \mathrm{~nm})$ and UVA $(315-380 \mathrm{~nm})$ radiant fluxes and their relationships with broadband global radiant flux at an eastern Mediterranean site. Agricultural and Forest Meteorology. 2009; 149: 11881200.

21. Martinez-Lozano J, Tena F, Utrillas P. Measurement and analysis of ultraviolet solar irradiation in Valencia, Spain. International Journal of Climatology. 1996; 16: 947-955.

22. Foyo-Moreno I, Vida J, Alados-Arboledas I. Ground-based ultraviolet (290$385 \mathrm{~nm}$ ) and broadband solar radiation measurements in south-eastern Spain. International Journal of Climatology. 1998; 18: 1389-1400.

23. CañadaJ, PedrósG, López A, Boscà J. Influence of the clearness index for the whole spectrum and of the relative optical air mass on UV solar irradiance for two locations in the Mediterranean area, Valencia and Córdoba. Journal of Geophysical Research. 2000; 110; 4759-4766.

24. Mantis H, Repapis C, Philandras C, Pañiatsos A, Zerefos C, Bais A. A 5-year climatology of solar erythemal ultraviolet in Athens, Greece. International Journal of Climatology. 2000; 20: 1237-1247.

25. Koronakis PS, fantos GK, Pañiatsos A, Kaldellis J, Garofalakis J, Koronakis J. Interrelations of UV-global/global/diffuse solar irradiance components and UV-global attenuation on air pollution episode days in Athens, Greece. Atmospheric Environment. 2002; 36: 3173-3181.

26. Kudish A, Evseev E. Statistical relationships between solar UVB and UVA radiation and global radiation measurements at two sites in Israel. International Journal of Climatology. 2000; 20: 759-770.

27. Kudish A., Evseev E. Analysis of erythemal UVB and UVA irradiance at Beer Sheva, Israel from 1994 through 2012. Renewable Energy. 2014; 63: 84-89.

28. Jacovides C, Boland J, Rizou D, Kaltsounides N, Theocharatos G. School Students participation in monitoring solar radiation components: Preliminary results for UVB and UVA solar radiant fluxes. Renewable Energy. 2012; 39, 367-374.

29. Kalogirou SA, Pashiardis S, Pashiardi A. Statistical analysis and intercomparison of erythemal solar radiation for Athalassa and Larnaca, Cyprus. Renewable Energy. 2017; 111: 580-597. 
30. Pashiardis S, Kalogirou SA, Pelengaris A. Statistical analysis and intercomparison of UVB and global radiation for Athalassa and Larnaca, Cyprus. SM Journal of Biometrics \& Biostatistics. 2017; 1: 1-15.

31. Jacovides C, Kaltsunides N, Hachioannou L, Stefanou L. An assessment of the solar radiation climate of the Cyprus environment. Renewable Energy. 1993; 3: 913-918.

32. Kambezidis C. Typical Meteorological Year for Nicosia. Theory and use guide. 1999

33. Kalogirou S, Pashiardis S, Pashiardi A. Statistical analysis and intercomparison of the global solar radiation at two sites in Cyprus. Renewable Energy. 2017; 101: 1102-1123.

34. World Meteorological Organization. WMO, 1987. Guidelines on the quality control of data from the World Radiometric Network. WCDP-3, WMO/TDNo.258, p 30, WMO, Geneva, Swittzerland.

35. Long CN, Dutton EG. Global Network recommended QC tests, V2.0, BSRN Technical Report. 2002.

36. Long CN, Shi Y. An automated quality assessment and control algorithm for surface radiation measurements. The Open Atmospheric Science Journal. 2008; 2: 23-37.
37. Muneer T. Solar Radiation and Daylight models. 2nd Edition. Oxford: Elsevier. 2004

38. Pashiardis S, Kalogirou S. Quality control of solar shortwave and terrestrial longwave radiation for surface radiation measurements at two sites in Cyprus. Renewable Energy. 2016; 96: 1015-1033.

39. Miguel A, Bilbao J, Aguilar R, Kambezidis H, Negro E. Diffuse solar irradiation model evaluation in the North Mediterranean belt area. Solar Energy. 2001; 70: 143-153.

40. Kasten F, Young AT. Revised optical air mass tables and approximation formula. Appl Opt. 1989; 28: 4735-4738.

41. Gueymard C. The sun's total and spectral irradiance for solar energy applications and solar radiation models. Solar Energy. 2004; 76: 423-453.

42. Mateos D, Miguel A, Bilbao J. Empirical models of UV total radiation and cloud effect study. International Journal of Climatology. 2010; 30: 1407-1415.

43. Bilbao J, Mateos D, Miguel A. Analysis and cloudiness influence on UV total irradiation. International Journal of Climatology. 2011; 31: 451-460. 